\title{
A place-based approach to fear of crime: A systematic review of app-based and crowdsourced measures
}

\author{
Authors \\ Reka Solymosi[1], David Buil-Gil[1], Laura Vozmediano [2], and Inês Sousa Guedes [3] \\ [1] Centre for Criminology and Criminal Justice, University of Manchester, UK \\ [2] University of the Basque Country, Spain \\ [3] University of Porto, Portugal \\ Corresponding author \\ Reka Solymosi. Centre for Criminology and Criminal Justice, Williamson Building, University \\ of Manchester, 176 Oxford Road, Manchester, M13 9QQ \\ Email: reka.solymosi@manchester.ac.uk
}

\begin{abstract}
Few researches have considered fear of crime as a context-specific experience. This paper promotes a place-based theoretical framework for studying crime perceptions through presenting app-based and crowdsourcing measures of perception of crime and place as a robust methodological framework. A systematic review of published studies that use crowdsourced or app-based measures to explore perceptions of crime was conducted. From the 27 studies that met our inclusion criteria, reported strengths and limitations were synthesized to determine key developments and common issues, illustrated with data from three app-based studies. We found consensus that app-based and crowdsourcing measures of fear of crime capture more precise spatial and temporal data alongside auxiliary information about the individual and the environment. Practical benefits, such as reduced cost of data collection and implementable outputs that are useful to practitioners were also highlighted. However, limitations around sampling biases, generalizability of findings, and the under-representation of certain areas persist.
\end{abstract}

\section{Keywords}

Fear of crime, environmental criminology, systematic review, Crowdsourcing, open data, mapping, perceived disorder, GIS

\section{Funding details}

This work was supported by the British Academy/ Leverhulme Small Grants under Grant SG171381.

\section{Acknowledgements}

The authors would like to thank Aiden Sidebottom and Juanjo Medina for comments that greatly improved the manuscript. This project was funded by the British Academy/ Leverhulme Small Grants (grant number SG171381). 


\begin{abstract}
Few researches have considered fear of crime as a context-specific experience. This paper promotes a place-based theoretical framework for studying crime perceptions through presenting app-based and crowdsourcing measures of perception of crime and place as a robust methodological framework. A systematic review of published studies that use crowdsourced or app-based measures to explore perceptions of crime was conducted. From the 27 studies that met our inclusion criteria, reported strengths and limitations were synthesized to determine key developments and common issues, illustrated with data from three app-based studies. We found consensus that app-based and crowdsourcing measures of fear of crime capture more precise spatial and temporal data alongside auxiliary information about the individual and the environment. Practical benefits, such as reduced cost of data collection and implementable outputs that are useful to practitioners were also highlighted. However, limitations around sampling biases, generalizability of findings, and the under-representation of certain areas persist.
\end{abstract}

\title{
Keywords
}

Fear of crime, environmental criminology, systematic review, Crowdsourcing, open data, mapping, perceived disorder, GIS 


\section{Introduction}

How does the environment influence the fear of crime? When and where do emotions of fear arise? Which contextual features lead people to perceive some areas as more crime-prone than others? It is important to answer these questions to tackle fear of crime and mitigate its negative individual and societal outcomes. Worry affects psychological wellbeing, ease of access to resources, and, in extreme cases, prevents people from leaving home (Hale, 1996). Worry has a wide societal impact affecting sense of community and punitiveness (Hale 1996); economic impact affecting housing prices (Ceccato and Wilhelmsson 2012) and business decisions (Casten and Payne 2008); and environmental impact through a reduction in walkability leading to increased use of high-emission private transport modes (McDonald, Deakin, and Aalborg 2010). Fear of crime is also often considered as an outcome when evaluating interventions such as hotspot policing (Braga, Papachristos and Hureau 2012), CCTV (Lim and Wilcox 2016), or 'broken windows' initiatives where neighborhood cleanup and zero-tolerance antisocial behavior policies are implemented. Approaches such as Crime Prevention Through Environmental Design (CPTED) (see for example, Armitage 2017 for a recent overview) and Crime Prevention through Urban Design and Planning (CP-UDP) (Politécnico di Milano, IAU île-de-France and Regione Emilia Romagna, 2007) also provide theoretical support for understanding how urban design and management have influence on fear of crime. This idea can be traced back to Newman's (1972) classic suggestions of physical design features being related to the fear of crime. 
Yet many empirical studies of fear of crime focus on individual factors, and much less research has considered fear of crime as a context-specific experience. This may be due partially to the dispositional bias in criminology, the tendency to highlight internal factors (personality, attitudes) over the causal role of the immediate environment (Clarke 1980; Sidebottom and Wortley 2015). Another explanation may be the lack of available data about fear of crime that describes the environmental context in which these experiences take place, making a placebased approach difficult to operationalize. To re-conceptualize the perception of crime and place as a function of the person and the environment, it is vital to better understand the contexts in which people experience more or less fear. In response, the last few years has seen several projects employ app-based and crowdsourcing tools in a bid to collect better data on specific experiences with fear of crime (Solymosi and Bowers 2017). The field is now at a point where these unique studies can be synthesized to create a comprehensive review and inform placebased study of fear of crime.

The aim of this paper is to promote a place-based theoretical framework for understanding perceptions of crime by promoting app and crowdsourced data collection. We achieve this through two objectives. First, we conduct a systematic review of published studies using these methods, extracting the key strengths and limitations of their research design. Second, we use data from three of these studies to illustrate key themes. Taken together, the systematic review and the empirical demonstrations provide an overview of this nascent field, and serve to produce guidance to those growing numbers of researchers adopting these techniques. 


\section{A place-based approach to fear of crime}

It has been recognized that fear of crime is transitory and situational (Fattah and Sacco 1989), and is influenced by the features of the situations in which people find themselves (Pain 2000; Rengifo and Bolton 2012). Environmental features such as 'signal crimes' and 'signal disorders' (e.g. graffiti or litter) communicate a break-down of social order (Innes 2004). Levels of prospect, refuge, and escape are associated with increased fear (Fisher and Nasar 1992). These situational features interact with person-specific factors known to affect worry about crime. For example, while women are consistently reported to experience higher level of fear of crime than men (LaGrange and Ferraro 1989), in certain situations, it is actually men who show higher fear than women (Moore and Breeze 2012). To begin to unpack how these contextual factors influence fear, researchers have explored the geography of fear. However, mapping fear of crime is not as straightforward as mapping crime.

Traditionally fear of crime is measured using survey questionnaires, which capture generalized anxieties instead of experienced fear events (Jackson 2013). Spatial information is most often operationalized as the respondents' home address (San Juan, Vozmediano, and Vergara 2010; Scarborough et al., 2010), representing where worried people live, rather than where they experience the incidents that make them worried. Although information about where participants live may be relevant in relation to some crimes, such as burglary, this is of little use when trying to understand where and when fear is experienced while using public space and how the individual-place-situation interactions may lead to a fear response. The studies which have begun to put fear of crime on the map make use of intensive, often qualitative methodologies, for example asking people to map areas they avoid due to fear of crime (Doran 
and Burgess 2012), asking people about their feeling of safety in one particular location (Fisher and Nasar 1995), following participants along a pre-planned route as they narrate their levels of fear (Nasar and Jones 1997), or asking people about signals in their environment that make them feel unsafe (Innes 2004). While such studies move towards attributing spatial information to people's perception of safety, none of them collect data on specific instances of fear experienced in day-to-day life. Rather, by asking people to reflect on general worry, they continue to tap into anxieties like surveys do (Gray et al. 2012).

In relation to the study of crime, the place-based approach focusing on immediate situational conditions that create a criminal opportunity (Wortley and Mazerolle 2008) has been well-supported by data which lends itself easily to mapping. Accordingly, the relationship between place and criminal behavior has been the focus of criminological research since Quetelet (1846) and Guerry (1833) began to map crime distribution across geographical areas (Ratcliffe 2010). This focus has produced many problem-solving interventions for crime prevention (Clarke 1983; Clarke and Bowers 2017). In order to achieve the same results for fear of crime, a truly place-based approach is needed.

As discussed above, this is not so straightforward for fear of crime. To support such a place-based theoretical framework with empirical data, people's experiences need to be captured as and when they happen. One approach is to use mobile applications that implement experience sampling methods (MacKerron 2011) or to deploy crowdsourcing projects which facilitate the near-real-time reporting of such experiences (Hudson-Smith, Batty, Crooks, and Milton 2009). Feasibility and pilot projects evaluating such app-based and crowdsourcing approaches to collect data about people's subjective perceptions of their environments and their experiences with fear of crime have begun to emerge. The state of research in this area is now 
such that it becomes appropriate to establish this new methodological approach as a robust framework. To do so, it is vital to synthesize the research currently piloting these methods. By bringing together findings of such pilots, place-based fear of crime research can move to rigorous implementation of this methodology to build empirical evidence-base to underlie study of environmental correlates of fear of crime. Furthermore, the results can inform the use of similar methodologies in other fields measuring emotional reactions to the immediate environment.

\section{Methods}

This paper takes a two-pronged approach to synthesizing the recent developments in the application of app-based and crowdsourcing methods to the study of perceptions of crime and place. First, we use a systematic review to identify relevant studies, and extract key strengths and limitations. Second, where possible, we illustrate these with data made available to the authors by three such papers. This section discusses each method in turn.

\section{Systematic Review}

A systematic review of crowdsourcing and app-based studies analyzing the fear of crime and associated constructs was conducted using a set of a priori searching, inclusion, and selection criteria for deciding eligibility. Our approach is based on the Preferred Reporting Items for Systematic Reviews and Meta-Analyses (PRISMA), and we include a PRISMA-style flow diagram, in line with similar systematic reviews in the domain of criminal justice research 
(Gravel, Bouchard, Descormiers, Wong, and Morselli, 2013; Lorenc et al., 2013; Wickramasekera, Wright, Elsey, Murray, and Tubeuf, 2015).

\section{Criteria}

Any observational, experimental, feasibility, or case studies employing app-based or crowdsourcing methodologies to collect data about perception of place in terms of safety or crime, were eligible for inclusion. In this case, crowdsourcing techniques were defined as those that involve harnessing the information and skills of large crowds of people into one collaborative project (Howe, 2005). Only peer reviewed published literature, including journal articles, books, book chapters and conference papers written in English language were examined.

\section{Searching}

We used keyword searches in three search engines: BASE (Bielefeld Academic Search Engine), Google Scholar and CORE (COnnecting Repositories). BASE and Google Scholar are two of the most popular multidisciplinary academic search engines, having more than 100 million and around 160 million indexed documents, respectively. CORE aggregates more than 135 million open access articles. Searches were conducted between December 2017 and March 2018. The search strategy used the following keywords:

((fear of crime) OR (worry about crime) OR (perceptions of security) OR (attitudes towards crime) OR (perceived disorder)) AND ((crowdsourcing) OR (mobile application) OR (web application) OR (open data))[1]

'Citation chasing' was further used to cross-reference articles from the bibliographies of selected publications (Lorenc et al., 2013). Finally, consultation with members of the research 
team and the corresponding authors of the selected papers was used to identify additional papers. This search returned 576 papers.

\section{Screening}

To select studies from the initial sample $(\mathrm{N}=576)$, the abstracts were coded as to whether or not they met the following inclusion criteria:

(a) The paper analyses or discusses app-based or crowdsourcing measures.

(b) The paper focuses on fear of crime, worry about crime, attitudes towards crime, perception of security or disorder.

Thus, all research analyzing or discussing other quantitative or qualitative measures (mainly survey data) and/or focusing on other social phenomena (e.g. crime, happiness) were excluded. Both studies using primary and secondary data, and publications critically discussing the new approaches were included. We included any type of study design, as long as it included app-based or crowdsourced data collection. With respect to the object of study, we did not limit our screening to any specific operational definition of fear of crime, worry about crime, attitudes towards crime, perceptions of security or perceived disorder. Papers making use of social media data such as Facebook or Twitter (e.g. Burnap et al. 2015; Erete et al. 2016; Kim et al. 2014; Quercia et al. 2015; Williams et al. 2017), were excluded, as they follow different methodologies than those discussed in this paper. Finally, we note that when the same data were analyzed by the same authors in more than one publication, all publications were selected and examined, as long as the publications used the data in meaningfully different ways (i.e. the papers presented original contributions). In sum, 27 publications (12 journal articles, 11 conference papers and 4 book chapters) were selected (see Figure 1). The count of book chapters does not include conference papers published in conference monographs and proceedings, 
which were counted as conference papers. Articles included commentaries (3) as well as original research articles (9), as the purpose was to extract critical analysis of strengths and limitations of the method, to which commentaries contribute to in substantial ways.

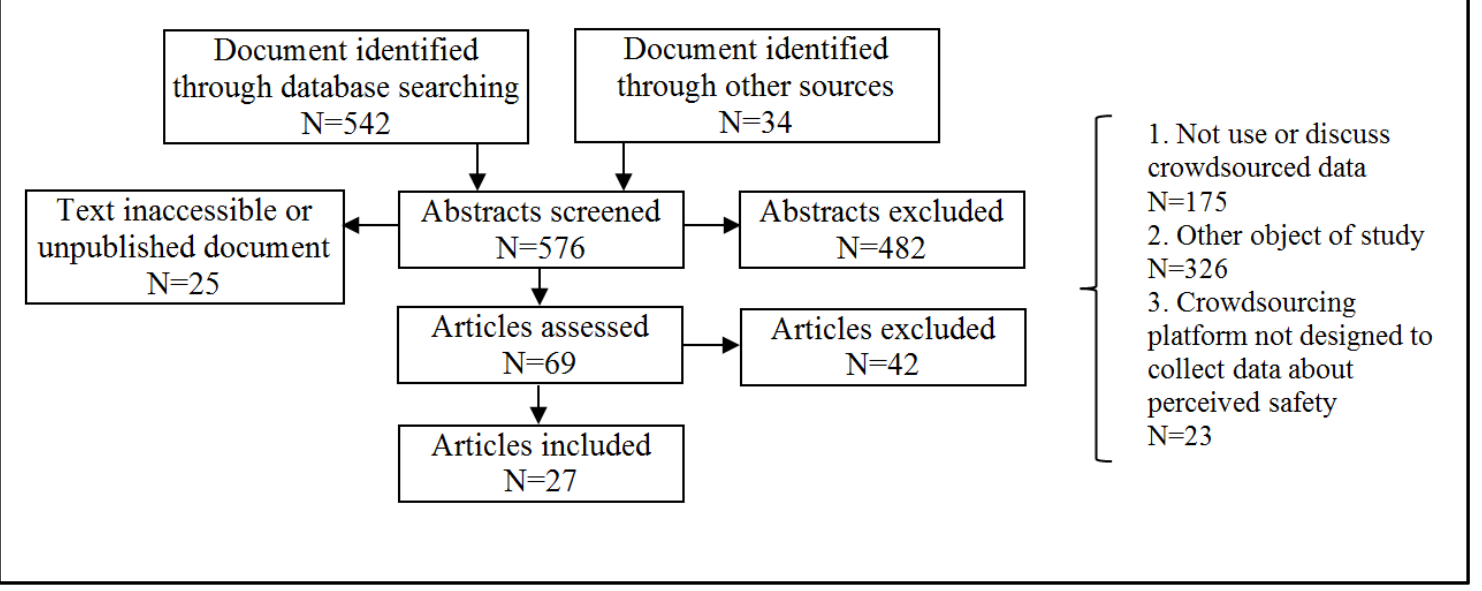

Figure I. Flowchart of literature through the systematic review.

\section{Data extraction and synthesis}

Data were extracted from selected articles using a standardized form to record information about the authors, the methodology, sample, main findings, and conclusions of the research. The extracted data were synthesized and coded into the following categories: substantive topic of study; measurement of the topic of study; methodological tool used; strengths identified; limitations identified; recommendations and future work; and substantive findings.

Thematic analysis of each publication was conducted to extract a list of the main strengths and weaknesses, which were then coded into the following subcategories: Capture the spatial-temporal specific nature of attitudes and emotions towards crime; record data on individual variables and specific types of fear/disorder; record data on architectural features; 
reduced cost of data collection; oriented to evidence-based policy making/urban planning; participation inequality; no screening questions; sample attrition; small sample sizes and low response rates; under-representation of certain areas and times; difficult to interpret results; limitations to generalize results; repeatedly asking about fear might increase/cause fear. An intercoder reliability check was carried out where after the initial coding, a second coder assessed the strengths and limitations identified in the paper using the same coding and categorizing protocol (Mouter and Vonk Noordergarf 2012). The results were that the second coder subsumed four of the limitations into one "sample issues" category, and suggested eliminating the "sample attrition" category, as it was only identified by one study. However since the coding criteria was to extract all strengths and limitations identified, the decision was made to retain this category.

\section{Exploratory Data Analysis}

The additional analysis section of a PRISMA review traditionally refers to sensitivity or subgroup analysis, however here, to supplement the systematic review, we present additional analysis of data from three exemplar studies using exploratory data analysis (see Tukey 1977). In particular, exploratory spatial data analysis (ESDA) (Bivand 2010) is used in order to illustrate the extracted themes with empirical data. The three studies (Solymosi et. Al., 2015, Buil-Gil, 2016; Vozmediano, Azanza, and Villamane 2017) were selected because the authors had access to the micro data from these. This section will now describe each application.

\section{Fear of Crime Application (FOCA)}

FOCA is a purpose-built mobile application that employs an experience sampling design asking participants about their perception of safety. Responses are recorded along with 
coordinates and a time stamp from the phone's inbuilt sensors. The application allows for retrospective annotation through the option of locating the area of interest on a map manually, once the participants have removed themselves from the dangerous location. Figure II shows the mobile app visual flowchart that represents the users' interaction flow with the application. In this study, we access data from 76 users who submitted 1344 reports between 2013-08-01 to 2013-09-02 (pilot) and 2014-06-20 to 2014-06-20 (main study). Of these, 1220 reports were "Not at all worried (90.8\%), 87 "Not very worried" (6.5\%), 29 "Fairly worried" (2.1\%) and 8 "Very worried" $(0.6 \%)$. The app was built by the principal researcher, and data hosted on a University server.

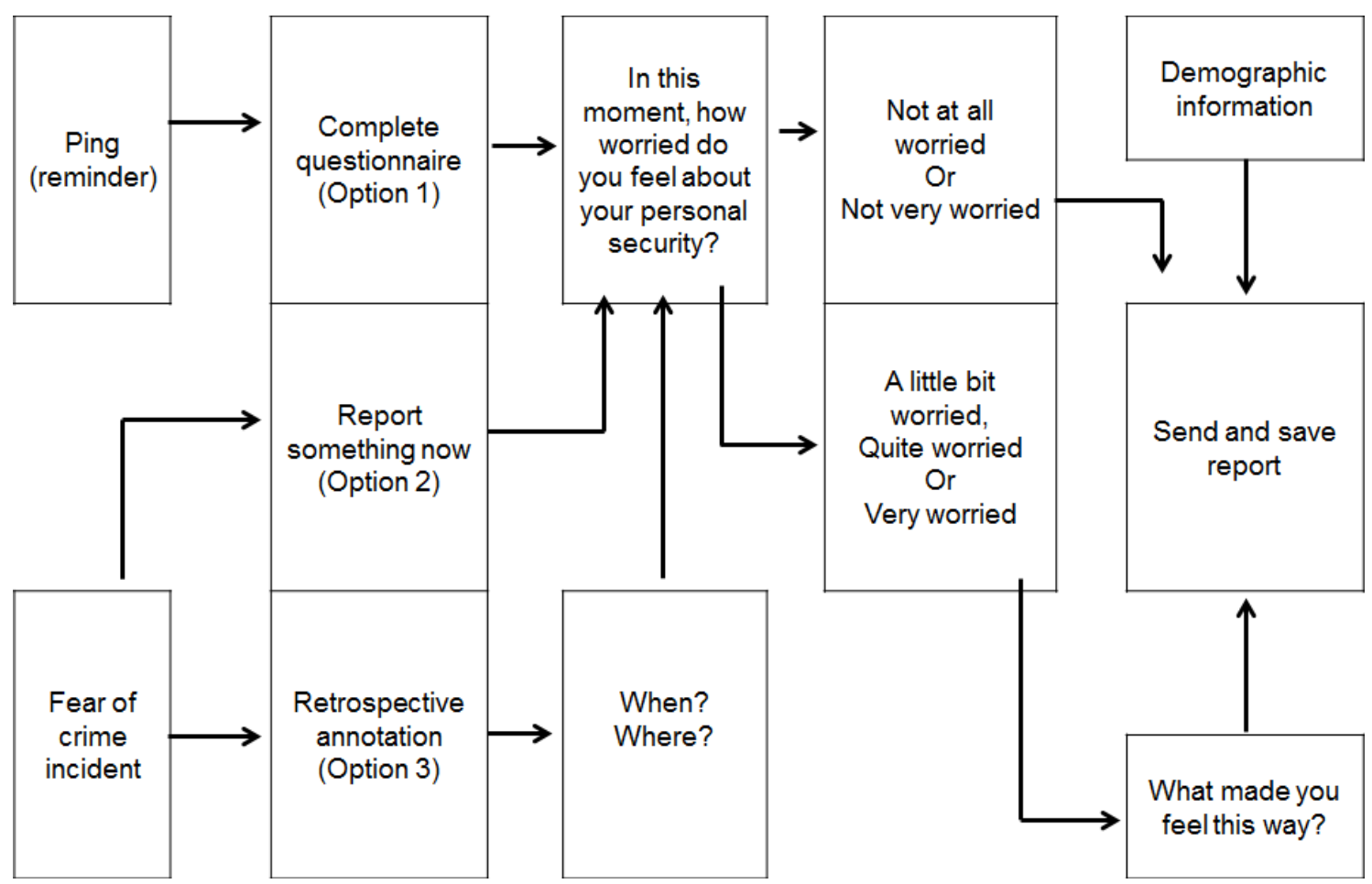

Figure II. FOCA visual flowchart. 


\section{InseguridApp}

InseguridApp is an Android application built by researchers at Crimina Research Centre of Miguel Hernandez University. It was deployed in Elche, Spain, and is available in Spanish language. It follows a similar structure and approach to FOCA, allowing users to self-report their fear of crime. InseguridApp did not include a retrospective map for reporting historic events. Figure III shows screenshots of this application. Data were collected from 32 users, who submitted 439 reports (315 "Not at all fearful" (71.7\%), 100 "Not very fearful" (22.8\%), 17 "Fairly fearful" (3.9\%) and 7 "Very fearful" (1.6\%) between 1st April 2016 and 31 st May 2016. The app was designed and built by the members of the research team and hosted in a private server.
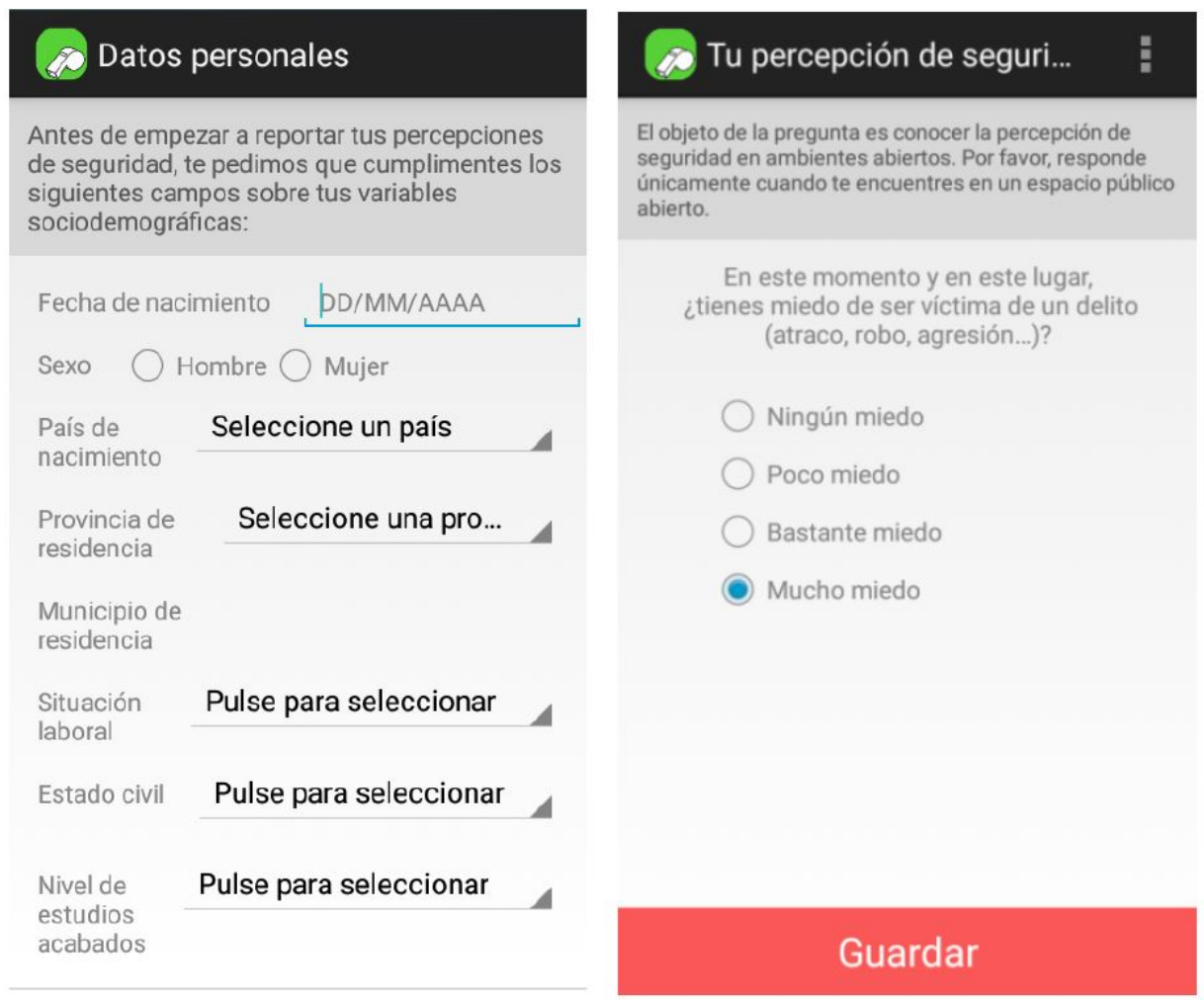

Figure III. Menus 1 and 2 of InseguridApp app and its translation to English. 


\section{Walkcap}

Walking capturer or 'Walkcap' is an Android application designed by researchers in the University of the Basque Country, Spain. Walkcap is available in Spanish, but multilingual support was included. The app was designed to capture walking routes: it detects when the users start walking and when they stop, collecting GPS points and time prints through the walk, mapping urban mobility of the participants. Once a day (time of the day can be chosen) the app prompts users to answer questions about a randomly selected recorded route from that day. Resulting data is of routes labelled with information about the age and gender of the person, the purpose of the route, if the participant walked alone, perceived levels of safety, beauty of the urban landscape, and reason for making the decision to walk. Figure IV shows screenshots of the application. Access was provided to data from 90 routes, and since the app asks for the evaluation of one random route per day and user, 34 of them had been evaluated and included data about safety perception. 

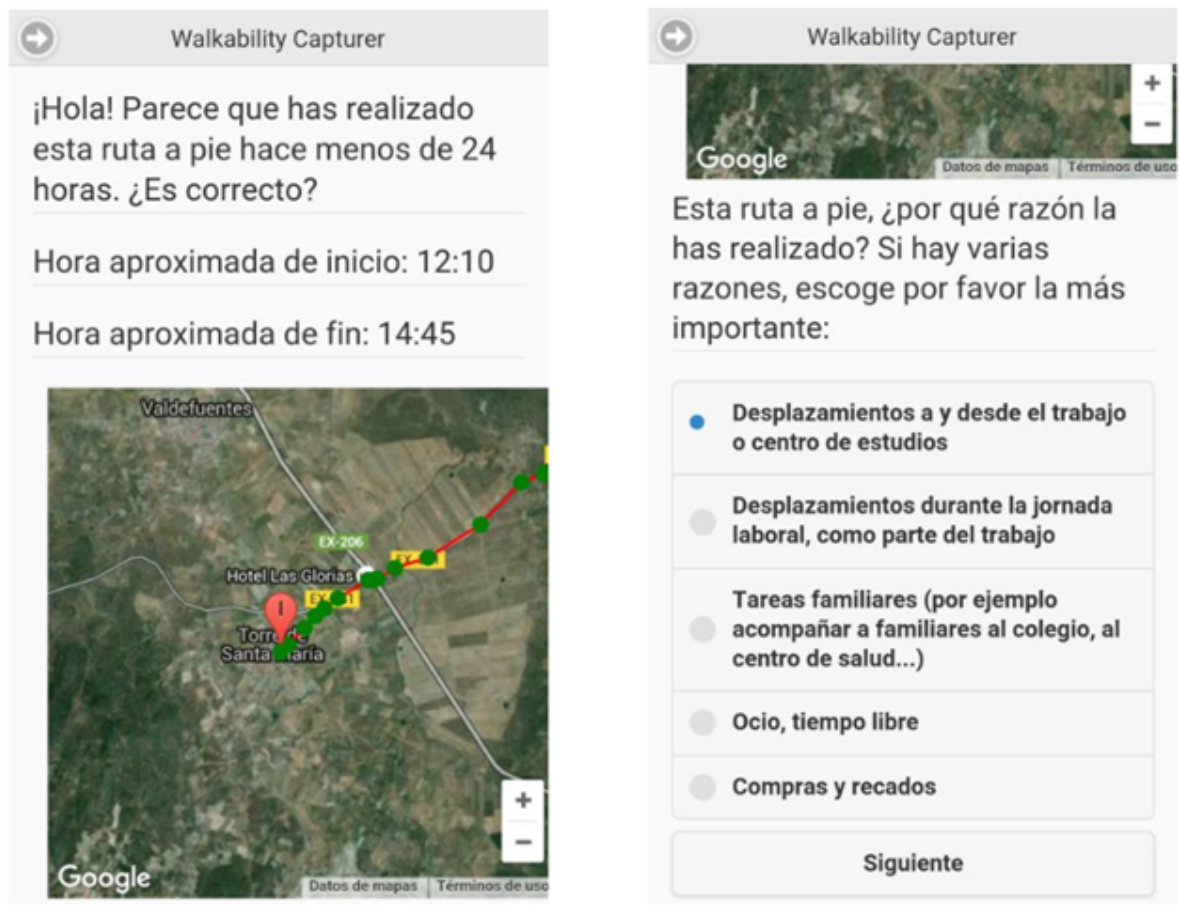

Esta ruta a pie, ¿por qué razón la has realizado? Si hay varias razones, escoge por favor la más importante:

- Desplazamientos a y desde el trabajo o centro de estudios

Desplazamientos durante la jornada laboral, como parte del trabajo

Tareas familiares (por ejemplo acompañar a familiares al colegio, al centro de salud...)

Ocio, tiempo libre

Compras y recados

Siguiente

Figure IV. Two menus on Walkcap: confirmation of the detected route and purpose and its translation to english

\section{Results}

\section{Descriptive Landscape of Studies}

Table 1 details the 27 studies included in our systematic review. Publications date from 2010 to 2018 and cover research in eleven countries. Each paper has been assigned a number in the first column of Table 1 which is used to refer to it in text. 
Table 1. Characteristics of the article included in the systematic literature review.

\begin{tabular}{|c|c|c|c|c|c|}
\hline & Paper & $\begin{array}{l}\text { Country of } \\
\text { institution } \\
\text { of first } \\
\text { author }\end{array}$ & $\begin{array}{l}\text { Substantiv } \\
\text { e topic }\end{array}$ & Operationalisation of topic & $\begin{array}{l}\text { Methodological } \\
\text { tool }\end{array}$ \\
\hline 1 & $\begin{array}{l}\text { Birenboim } \\
(2015)\end{array}$ & Netherlands & $\begin{array}{l}\text { Sense of } \\
\text { security }\end{array}$ & $\begin{array}{l}\text { Evaluate the momentary sense } \\
\text { of security from } 1 \text { to } 5\end{array}$ & $\begin{array}{l}\text { Self-built mobile } \\
\text { app }\end{array}$ \\
\hline 2 & $\begin{array}{l}\text { Blom et al. } \\
(2010)\end{array}$ & India & $\begin{array}{l}\text { Feeling of } \\
\text { security }\end{array}$ & $\begin{array}{l}\text { Green or red tag to indicate } \\
\text { locations where they feel } \\
\text { comfortable or uncomfortable }\end{array}$ & $\begin{array}{l}\text { Self-built mobile } \\
\text { app }\end{array}$ \\
\hline 3 & $\begin{array}{l}\text { Candeia et } \\
\text { al. }(2017)\end{array}$ & Brazil & $\begin{array}{l}\text { Perceived } \\
\text { safety }\end{array}$ & $\begin{array}{l}\text { Choose "which place looks } \\
\text { safer?" from two images }\end{array}$ & $\begin{array}{l}\text { Self-built } \\
\text { website or } \\
\text { online platform }\end{array}$ \\
\hline 4 & $\begin{array}{l}\text { Chataway } \\
\text { et al. (2017) }\end{array}$ & Australia & $\begin{array}{l}\text { Fear of } \\
\text { crime / } \\
\text { perceived } \\
\text { disorder }\end{array}$ & $\begin{array}{l}\text { Frequency of worry: scale } \\
\text { between } 1 \text { (Not once in the last } \\
\text { month) to } 4 \text { (Everyday) / } \\
\text { Perceived disorder: how much } \\
\text { of a problem certain conditions } \\
\text { (e.g. vandalism/graffiti, rubbish, } \\
\text { drinking) are in the immediate } \\
\text { area, between } 1 \text { and } 4\end{array}$ & $\begin{array}{l}\text { Self-built mobile } \\
\text { app }\end{array}$ \\
\hline 5 & $\begin{array}{l}\text { Dubey et al. } \\
(2016)\end{array}$ & India & $\begin{array}{l}\text { Perceived } \\
\text { safety }\end{array}$ & $\begin{array}{l}\text { Choose "which place looks } \\
\text { safer?" from two images }\end{array}$ & $\begin{array}{l}\text { Self-built } \\
\text { website or } \\
\text { online platform }\end{array}$ \\
\hline 6 & $\begin{array}{l}\text { Gómez et } \\
\text { al. (2016) }\end{array}$ & Colombia & $\begin{array}{l}\text { Perception } \\
\text { of security }\end{array}$ & $\begin{array}{l}\text { Trace a polygonal area on a } \\
\text { map and quantify the level of } \\
\text { risk and uncertainty between } 0 \\
\text { and } 10\end{array}$ & $\begin{array}{l}\text { Self-built } \\
\text { website or } \\
\text { online platform }\end{array}$ \\
\hline 7 & $\begin{array}{l}\text { Hamilton et } \\
\text { al. (2011) }\end{array}$ & Australia & $\begin{array}{l}\text { Perceived } \\
\text { safety }\end{array}$ & $\begin{array}{l}\text { Choose between two } \\
\text { scared/safe emoticons }\end{array}$ & $\begin{array}{l}\text { Self-built mobile } \\
\text { app }\end{array}$ \\
\hline 8 & $\begin{array}{l}\text { Harvey et } \\
\text { al. }(2015)\end{array}$ & USA & $\begin{array}{l}\text { Perceived } \\
\text { safety }\end{array}$ & $\begin{array}{l}\text { Choose "which place looks } \\
\text { safer?" from two images }\end{array}$ & $\begin{array}{l}\text { Website or } \\
\text { online platform }\end{array}$ \\
\hline 9 & $\begin{array}{l}\text { Innes } \\
(2015)\end{array}$ & UK & $\begin{array}{l}\text { Fear of } \\
\text { crime }\end{array}$ & $\begin{array}{l}\text { "In this moment, how worried } \\
\text { are you about becoming a victim } \\
\text { of crime?" }\end{array}$ & Mobile app \\
\hline 10 & $\begin{array}{l}\text { Jackson } \\
\text { and Gouseti } \\
(2015)\end{array}$ & UK & $\begin{array}{l}\text { Fear of } \\
\text { crime }\end{array}$ & $\begin{array}{l}\text { "In this moment, how worried } \\
\text { are you about becoming a victim } \\
\text { of crime?" }\end{array}$ & Mobile app \\
\hline 11 & $\begin{array}{l}\text { Jones et al. } \\
(2011)\end{array}$ & UK & $\begin{array}{l}\text { Fear of } \\
\text { crime }\end{array}$ & $\begin{array}{l}\text { Note level of immediate } \\
\text { happiness in relation to personal } \\
\text { safety, between } 1 \text { and } 4\end{array}$ & $\begin{array}{l}\text { Self-built mobile } \\
\text { app }\end{array}$ \\
\hline 12 & $\begin{array}{l}\text { Kyttä et al. } \\
(2014)\end{array}$ & Finland & $\begin{array}{l}\text { Perceived } \\
\text { safety }\end{array}$ & $\begin{array}{l}\text { Locate on a map all possible } \\
\text { fearful places and danger } \\
\text { locations }\end{array}$ & $\begin{array}{l}\text { Self-built } \\
\text { website or } \\
\text { online platform }\end{array}$ \\
\hline 13 & $\begin{array}{l}\text { Leitner and } \\
\text { Kounadi } \\
(2015)\end{array}$ & USA & $\begin{array}{l}\text { Fear of } \\
\text { crime }\end{array}$ & $\begin{array}{l}\text { "In this moment, how worried } \\
\text { are you about becoming a victim } \\
\text { of crime?" }\end{array}$ & Mobile app \\
\hline
\end{tabular}




\begin{tabular}{|c|c|c|c|c|c|}
\hline 14 & $\begin{array}{l}\text { Li et al. } \\
\text { (2015) }\end{array}$ & USA & $\begin{array}{l}\text { Perceived } \\
\text { safety }\end{array}$ & $\begin{array}{l}\text { Choose "which place looks } \\
\text { safer?" from two images }\end{array}$ & $\begin{array}{l}\text { Website or } \\
\text { online platform }\end{array}$ \\
\hline 15 & $\begin{array}{l}\text { Naik et al. } \\
(2014)\end{array}$ & USA & $\begin{array}{l}\text { Perceived } \\
\text { safety }\end{array}$ & $\begin{array}{l}\text { Choose "which place looks } \\
\text { safer?" from two images }\end{array}$ & $\begin{array}{l}\text { Website or } \\
\text { online platform }\end{array}$ \\
\hline 16 & $\begin{array}{l}\text { Ordonez } \\
\text { and Berg } \\
(2014)\end{array}$ & USA & $\begin{array}{l}\text { Perceived } \\
\text { safety }\end{array}$ & $\begin{array}{l}\text { Choose "which place looks } \\
\text { safer?" from two images }\end{array}$ & $\begin{array}{l}\text { Website or } \\
\text { online platform }\end{array}$ \\
\hline 17 & $\begin{array}{l}\text { Pánek et al. } \\
(2017 a)\end{array}$ & $\begin{array}{l}\text { Czech } \\
\text { Republic }\end{array}$ & $\begin{array}{l}\text { Perceived } \\
\text { criminality / } \\
\text { Perceived } \\
\text { noise }\end{array}$ & $\begin{array}{l}\text { Trace a polygonal area, line or } \\
\text { point on a map and quantify the } \\
\text { level of annoyance between } 1 \\
\text { and } 6\end{array}$ & $\begin{array}{l}\text { Self-built } \\
\text { website or } \\
\text { online platform }\end{array}$ \\
\hline $\begin{array}{l}18 \\
19\end{array}$ & $\begin{array}{l}\text { Pánek et al. } \\
\text { (2017b, } \\
\text { 2018) }\end{array}$ & $\begin{array}{l}\text { Czech } \\
\text { Republic }\end{array}$ & $\begin{array}{l}\text { Perceived } \\
\text { safety }\end{array}$ & $\begin{array}{l}\text { "Mark places where you feel } \\
\text { unsafe during the night-time / } \\
\text { day-time" }\end{array}$ & $\begin{array}{l}\text { Self-built } \\
\text { website or } \\
\text { online platform }\end{array}$ \\
\hline 20 & $\begin{array}{l}\text { Pödör et al. } \\
\text { (2016) }\end{array}$ & Hungary & $\begin{array}{l}\text { Fear of } \\
\text { crime }\end{array}$ & $\begin{array}{l}\text { "Indicate [with polygons on a } \\
\text { map] those places where you } \\
\text { feel fear of crime" }\end{array}$ & $\begin{array}{l}\text { Self-built } \\
\text { website or } \\
\text { online platform }\end{array}$ \\
\hline 21 & $\begin{array}{l}\text { Porzi et al. } \\
\text { (2015) }\end{array}$ & Italy & $\begin{array}{l}\text { Perceived } \\
\text { safety }\end{array}$ & $\begin{array}{l}\text { Choose "which place looks } \\
\text { safer?" from two images }\end{array}$ & $\begin{array}{l}\text { Website or } \\
\text { online platform }\end{array}$ \\
\hline 22 & $\begin{array}{l}\text { Salesses et } \\
\text { al. (2013) }\end{array}$ & USA & $\begin{array}{l}\text { Perceived } \\
\text { safety }\end{array}$ & $\begin{array}{l}\text { Choose "which place looks } \\
\text { safer?" from two images }\end{array}$ & $\begin{array}{l}\text { Self-built } \\
\text { website or } \\
\text { online platform }\end{array}$ \\
\hline 23 & $\begin{array}{l}\text { Solymosi et } \\
\text { al. (2015) }\end{array}$ & UK & $\begin{array}{l}\text { Fear of } \\
\text { crime }\end{array}$ & $\begin{array}{l}\text { "In this moment, how worried } \\
\text { are you about becoming a victim } \\
\text { of crime?" }\end{array}$ & $\begin{array}{l}\text { Self-built mobile } \\
\text { app }\end{array}$ \\
\hline 24 & $\begin{array}{l}\text { Solymosi et } \\
\text { al. }(2017)\end{array}$ & UK & $\begin{array}{l}\text { Perceived } \\
\text { disorder }\end{array}$ & $\begin{array}{l}\text { Report a problem (e.g. graffiti, } \\
\text { litter) on an online map. }\end{array}$ & $\begin{array}{l}\text { Website or } \\
\text { online platform }\end{array}$ \\
\hline 25 & $\begin{array}{l}\text { Solymosi } \\
\text { and Bowers } \\
\text { (2018) }\end{array}$ & UK & $\begin{array}{l}\text { Fear of } \\
\text { crime / } \\
\text { perceived } \\
\text { disorder }\end{array}$ & $\begin{array}{l}\text { Fear of crime: "In this moment, } \\
\text { how worried are you about } \\
\text { becoming a victim of crime?" / } \\
\text { Perceived disorder: Report a } \\
\text { problem (e.g. graffiti, litter) on an } \\
\text { online map }\end{array}$ & $\begin{array}{l}\text { Self-built mobile } \\
\text { app / Website or } \\
\text { online platform }\end{array}$ \\
\hline $\begin{array}{l}26 \\
27\end{array}$ & $\begin{array}{l}\text { Traunmuell } \\
\text { er et al. } \\
(2015 \\
2016)\end{array}$ & UK & $\begin{array}{l}\text { Perceived } \\
\text { safety }\end{array}$ & $\begin{array}{l}\text { Indicate "how safe you would feel } \\
\text { on this street?" using a built as a } \\
70 \text { point / } 100 \text { point Likert-scale }\end{array}$ & $\begin{array}{l}\text { Self-built } \\
\text { website or } \\
\text { online platform }\end{array}$ \\
\hline
\end{tabular}

Six papers discuss data recorded from self-built mobile applications $(1,2,4,7,11,23)$, eleven inspect crowdsourced data from a self-built online platform $(3,5,6,12,17,18,19,20$, $22,26,27)$, three discuss data recorded from an already existing mobile application $(9,10,13)$, 
and six analyze data from already existing online platforms $(8,14,15,16,21,24)$. One (25) analyses data from both methods.

Eighteen studies focus on "perceived security" $(1,2,3,5,6,7,8,12,14,15,16,17,18$, $19,21,22,26,27)$, eight analyze "fear of crime" $(4,9,10,11,13,20,23,25)$, and four studies examine "perceived disorder" $(4,17,24,25)$. Three studies tackle both fear of crime and at least one type of perceived disorder $(4,17,25)$. Interestingly, the approaches to operationalizing these concepts vary widely between researchers (see Table 1). The distinct approaches to wording in the measurement of fear and perception ranges from questions originating from past fear of crime research $(4,23,25)$ to asking people to rank places $(3,5,14,15,16,21,22)$, or asking about annoyance (17). This is important to consider, as the way that fear of crime is operationalized affects results (Collins, 2016).

All publications recorded geographical information, creating spatially explicit data about people's experiences with fear of crime, supporting a place-based approach to evaluating attitudes towards crime. Three different approximations were used to record spatial information. Mobile phone GPS signal was used by nine publications to geocode users' locations $(1,2,7,9$, $10,11,13,23,25)$. Ten papers requested participants to assess their safety perceptions for specific images, which were geocoded by researchers $(3,5,8,14,15,16,21,22,26,27)$. Finally, ten studies asked users to trace or point out on an online map places where they felt unsafe or perceived signs of disorder $(4,6,12,17,18,19,20,23,24,25)$. Some applications allowed two approaches, for example Solymosi et al. (2015) allowed both real-time reports using GPS, and retrospective reporting using a map. The temporal dimension (day and exact time) of each report was also recorded and analyzed in seven cases (1, 2, 4, 11, 23, 24, 25). 


\section{Identified strengths and limitations}

To learn from these diverse applications and advance current discourse, the key strengths and limitations identified by each paper were coded and synthesized.

\section{Strengths}

Our systematic review identified five strengths associated with this approach (Table 2). The most commonly identified strength is the ability to capture the transitory and geographically specific nature of fear of crime. Coded as "Capture the spatial-temporal specific nature of attitudes and emotions towards crime", this theme was mentioned by twenty-three publications $(1,2,3,4,5,6,7,8,9,10,11,12,13,14,16,18,19,20,21,22,23,24,25)$. For example, Birenboim (2016), who developed a mobile phone application to measure perceptions of security during a music festival in Jerusalem, noted that new mobile technologies allow for a more granular resolution in terms of spatial and temporal precision when users report their subjective perception of security. Gómez et al. (2016) and Kyttä et al. (2014), examining perceived security in Colombia and Finland respectively, argue that such precision might be used to map real-time experiences in its exact location, at the smallest possible spatial scale. The advantage is "to be able to un-erroneously associate them with elements of the environmental backcloth such as incivilities, crime, and disorder" (Solymosi et al. 2015:198). Some papers employ spatial analyses such as Kernel density estimation and Spearman's spatial correlation to identify hotspots of fear, and explore the environmental context associated with these (e.g. 1, 17, 18, 19, 25). This is the key strength and innovation of these methods which allows for the framing of fear of crime as a situation-specific experience. To demonstrate, Figure V shows a map of points of fear of crime reports made in London using FOCA, and Figure VI a similar map from the results of InseguridApp made in Elche. 


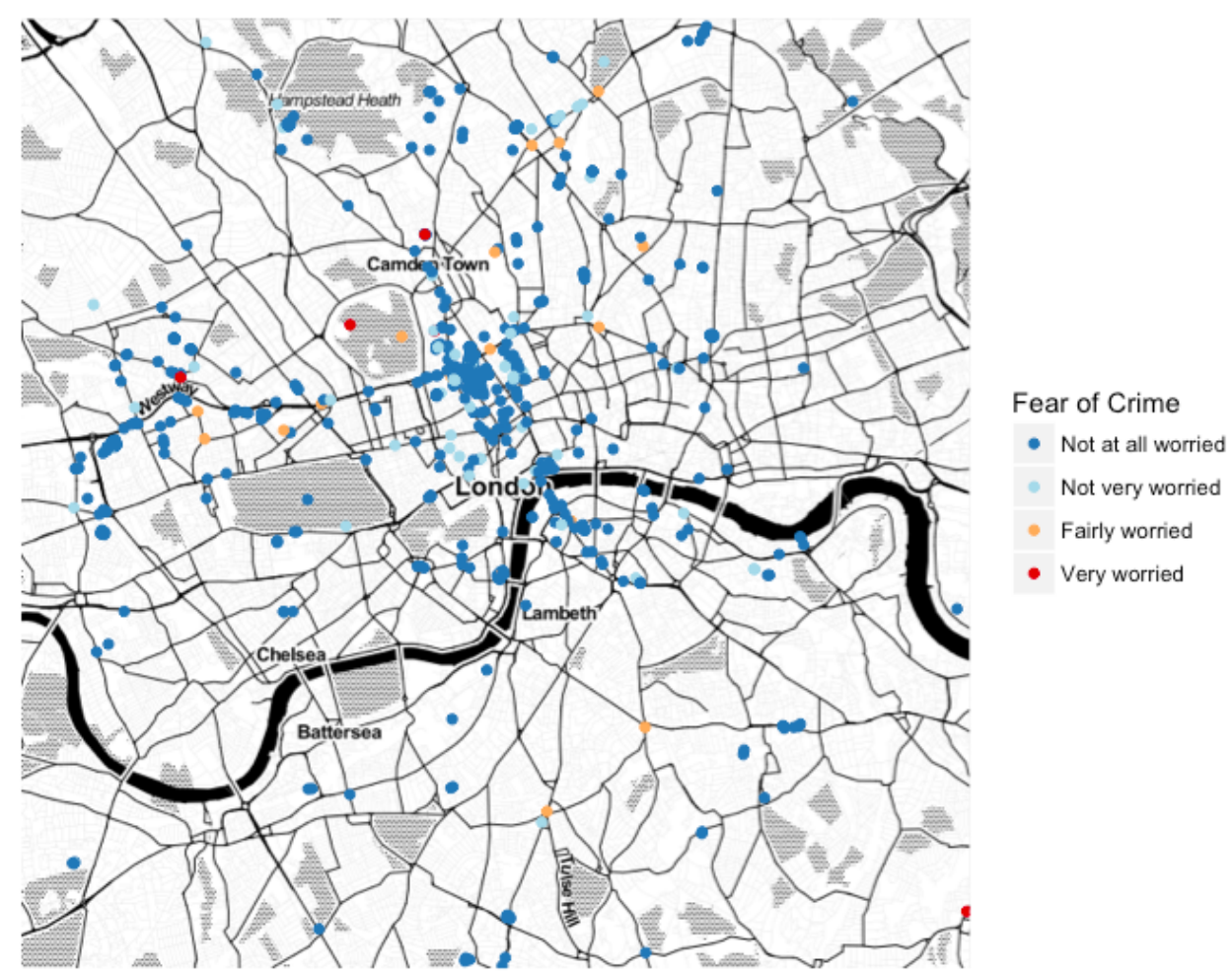

Figure V. Reports of fear of crime in London by FOCA users.

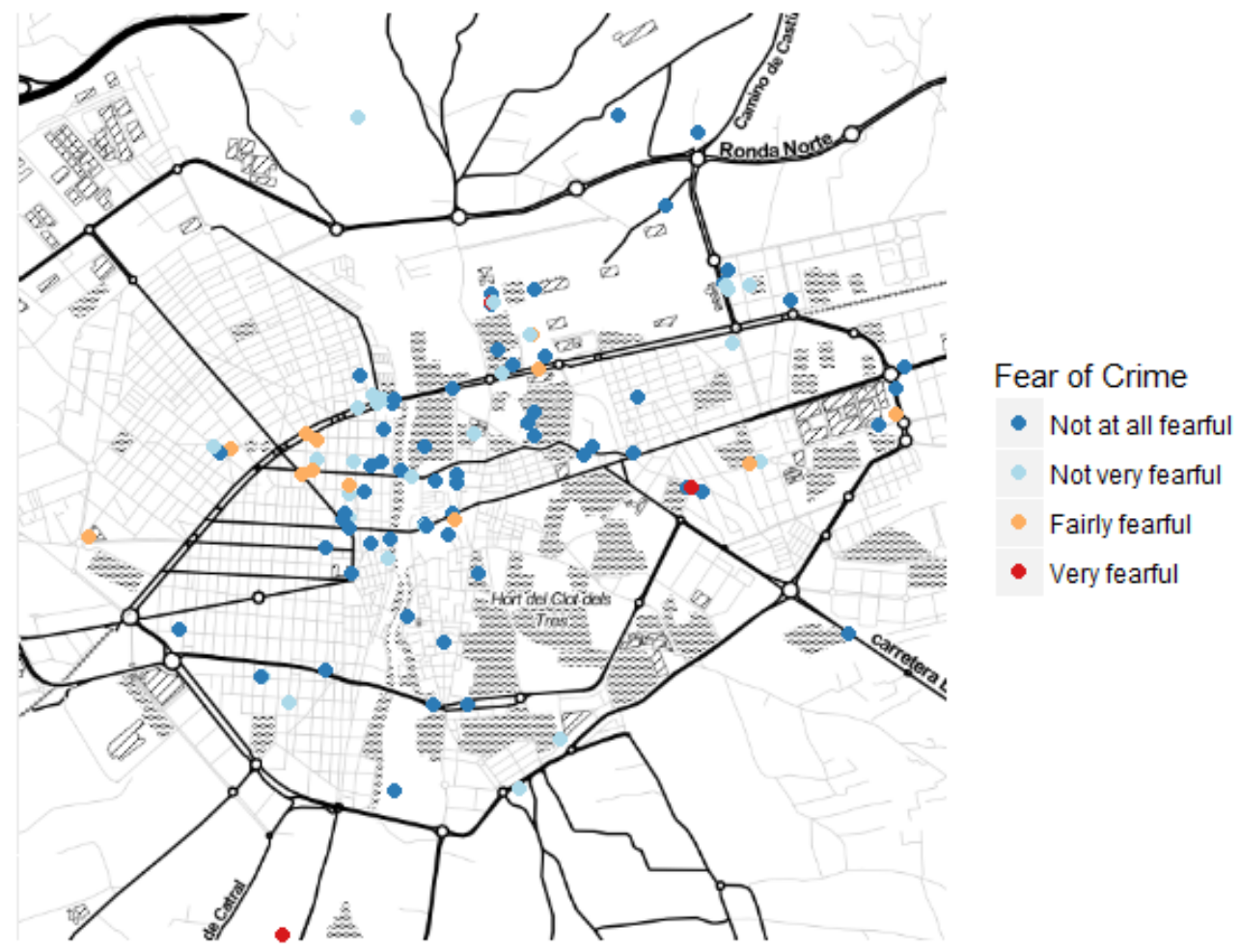

Figure VI. Reports of fear of crime in Elche by InseguridApp users. 
This low-level granularity reveals that there can be within-neighborhood variation of experiences of fear, and affirms that it is possible to situate people's experiences in the local environmental context.

Coded as the ability to "record data on individual variables and specific types of fear/disorder", twelve papers note that like traditional approaches, crowdsourcing applications also record data on socio-demographic variables of users, such as age, gender, place of residence and income $(3,9,12,13,17,18,19,20,22,24,26,27)$. While this feature is present in traditional measures, a particular strength of its application here was identified by five papers $(4,6,12,24$, 25) whereby it is possible to pair these with more dynamic and context-specific information, providing granularity in contextual knowledge around the fear event. To illustrate, we can explore the individual variable "familiarity with an area" collected by FOCA. The odds of reporting worry while outside home postcode area (non-familiarity) is 3 times the odds of reporting worry inside home postcode area (odds ratio $=3.33,95 \%$ confidence intervals: 1.2 10.6, $\mathrm{p}=0.025, \mathrm{AIC}=164.41$, model chi square $=0.018$, likelihood ratio $\mathrm{r}$ square $=0.034$ ). Taking this proxy measure to reflect familiarity with an area provides empirical support to the hypothesis that people are more likely to be worried in areas they are not familiar with. This effect holds when adding control variables to the model to account for time of day (hour) and day of the week (odds ratio $=3.31,95 \%$ confidence intervals: $1.2-10.6, \mathrm{p}=0.028$, AIC $=$ 163.45 , model chi square $=0.008$, likelihood ratio $r$ square $=0.124)$. Evidently collecting such data allows exploration of the dynamic, person and situation specific variables that affect fear. Similarly, the ability to "record data on architectural features" was mentioned by twenty of the papers, providing further context to people's experiences $(1,2,3,4,5,8,11,12$, $14,15,16,17,18,19,20,21,22,23,26,27)$. To illustrate, six high fear locations identified 
through a spatial density analysis of the InseguridApp data were observed as part of an exploratory approximation. Figure VII shows daytime and nighttime photos of two such locations where users of InseguridApp reported feeling most unsafe. Their features were then coded: four locations were narrow alleys and streets with lack of prospect, three contained places where potential offenders could conceal, two were closed-in pathways or dead ends, three were poorly lit at night, two contained observed cues of physical disorder (e.g. graffiti, rubbish bags in the streets), and three had a scarce presence of neighbors and passersby in public spaces. This information can be used to motivate testing hypotheses of relationships between such environmental features and fear of crime in larger sample sizes. 

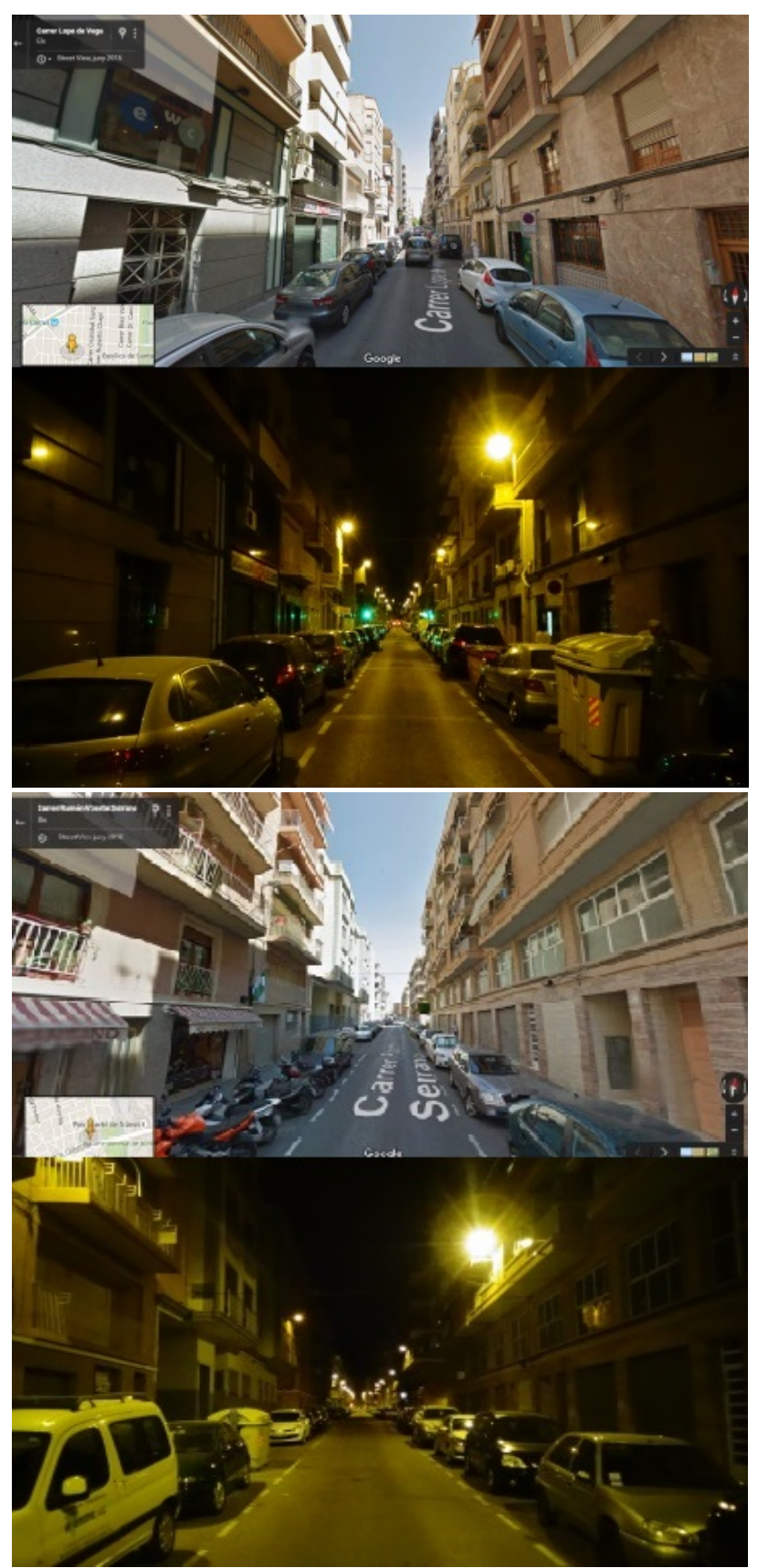

Figure VII. Daytime and nighttime photos of two locations reported as unsafe by InseguridApp users.

A technical consideration identified was the "reduced cost of data collection", mentioned by eleven papers $(3,4,6,11,14,16,21,23,24,25,26)$. Crowdsourcing methodologies reduce data collection costs while possibly generating large sample sizes. For example, Salesses et al. (2013) asked volunteers to choose which place looks safer from two 
images on an online platform, reaching 208,738 reports from participants from 91 countries. The number of reports analyzed by Dubey et al. (2016) resulted in more than 1,150,000 pairwise comparisons. The FixMyStreet dataset used by Solymosi et al. (2017) and Solymosi and Bowers (2018) contained more than 275,000 entries. These sorts of sample sizes are usually costly to obtain using traditional, survey-based, or experience-sampling methodologies.

Finally, twenty-one papers suggest that policy makers and security planners can use precise geocoded data to design environments less likely to produce fear (coded as "Oriented to evidence-based policy making/urban planning") $(2,3,4,5,6,7,8,9,11,12,14,15,16,17$, $18,19,20,22,23,24,25)$. For example, Candeia et al. (2017:143) argue that crowdsourced geocoded data can be used by urban planners to "understand what interventions may be applied to areas perceived as less pleasant or safe". Some applications, such as FixMyStreet, even submit users' reports to local authorities to address the issue being reported (Solymosi et al. 2017).

Table 2. Summary table of crowdsourced data in fear of crime research's strengths.

\begin{tabular}{|c|c|c|}
\hline Strength & $\mathbf{N}$ & Papers \\
\hline $\begin{array}{l}\text { Capture the spatial- } \\
\text { temporal specific nature of } \\
\text { attitudes and emotions } \\
\text { towards crime. }\end{array}$ & $\begin{array}{l}23 \\
(81.5 \%)\end{array}$ & $\begin{array}{l}1,2,3,4,5,6,7,8,9,10,11,12,13,14,16,18,19 \\
20,21,22,23,24,25 .\end{array}$ \\
\hline $\begin{array}{l}\text { Record data on individual } \\
\text { variables and specific types } \\
\text { of fear/disorder. }\end{array}$ & $\begin{array}{l}12 \\
(44.4 \%)\end{array}$ & $3,9,12,13,17,18,19,20,22,24,26,27$ \\
\hline $\begin{array}{l}\text { Record data on } \\
\text { architectural features. }\end{array}$ & $\begin{array}{l}20 \\
(74.1 \%)\end{array}$ & $\begin{array}{l}1,2,3,4,5,8,11,12,14,15,16,17,18,19,20,21 \text {, } \\
22,23,26,27 .\end{array}$ \\
\hline $\begin{array}{l}\text { Reduced cost of data } \\
\text { collection. }\end{array}$ & $\begin{array}{l}11 \\
(40.7 \%)\end{array}$ & $3,4,6,11,14,16,21,23,24,25,26$ \\
\hline $\begin{array}{l}\text { Oriented to evidence-based } \\
\text { policy making/urban } \\
\text { planning. }\end{array}$ & $\begin{array}{l}21 \\
(77.8 \%)\end{array}$ & $\begin{array}{l}2,3,4,5,6,7,8,9,11,12,14,15,16,17,18,19,20 \text {, } \\
22,23,24,25 .\end{array}$ \\
\hline
\end{tabular}




\section{Limitations}

Just as knowing the advantages of a method is important, the limitations identified by early adopters are vital for setting research agendas for methodological improvement, and providing tales of caution. Table 3 lists the themes into which the limitations extracted from each paper were coded. Each limitation is discussed in more detail below with suggestions to overcome or address them.

Many of the limitations identified by our systematic review can be subsumed into the overarching category of issues around sampling. While a common and widely researched problem with sample surveys, this issue is revisited each time a new platform for collecting data is introduced (e.g. Bethlehem and Biffignandi 2012; Eliott and Valliant 2017). Therefore it is no surprise that sampling issues are the most common limitation identified.

Perhaps the most unique issue to crowdsourced data collection is participation inequality, noted by thirteen publications $(2,4,8,13,17,18,19,20,23,24,25,26,27)$. This can be split into two issues. One is self-selection bias of participants: males tend to be more represented than females, and young citizens are overrepresented compared to older groups, as “certain demographics of crowdworkers [are] not reached" (e.g. Traunmueller et al. 2015:132). As noted by Chataway et al. (2017), even experience sampling techniques struggle to reduce the bias arising from self-selection in participant recruitment. Though Jones et al. (2011) argue, after having tested their mobile app with senior citizens, that new methodological approaches should not be a major barrier to record data from various demographic groups; and Salesses et al. (2013) argue that results obtained from analyzing the Place Pulse 1.0 dataset are not driven by biases from gender, age or country of residence. Another issue however is around the 
participation inequality within the sample; a small group of participants are often responsible most reports $(2,23,24,25)$. For example, with FixMyStreet data, one fourth of all reports had been produced by one percent of users, while $73 \%$ of people in the sample contributed only once (Solymosi et al. 2017). One way to address this is at the data collection stage; in order to reduce the bias in crowdsourced data, four papers $(1,4,23,25)$ suggests implementing Experience Sampling Method (ESM) or Ecological Momentary Assessment (EMA) (see Csikszentmihalyi 2014) as sampling design approaches. By making use of ESM/EMA sampling techniques, the bias arising from unequal participation by different users and the subjective decision about when and where to report might be reduced (Chataway et al. 2017), and aggregated maps produced from recorded data can be regarded as more reliable, though estimates of error still would need to be provided in each area (Buil-Gil et al. 2019).

Another methodological approach to overcome this bias in crowdsourcing platforms is to combine crowdsourcing and machine learning tools which train computational algorithms to reproduce patterns captured by human participation at unreported or underreported geographical areas $(3,5,15,16,21,22)$. However, computational modeling approaches might be limited to predicting perceived safety in these areas with similar architectural styles and urban planning of the areas for which crowdsourced data is available (Candeia et al. 2017; Harvey et al. 2015; Naik et al. 2014).

A sampling issue specific to any study design that requires ongoing participation is sample attrition over time. While only one study in this review highlighted the issue (2), it was also observed in the data collected by InseguridApp (Figure VIII), and has major implications for biasing results. Blom et al. (2010) found that application use, and consequently the number of data points collected, is especially high during the first few days after its launch. Participation 
then decreases progressively during the following weeks. Thus, the decision about when to start the data collection might bias the final results due to seasonal variation associated with the time of launch.

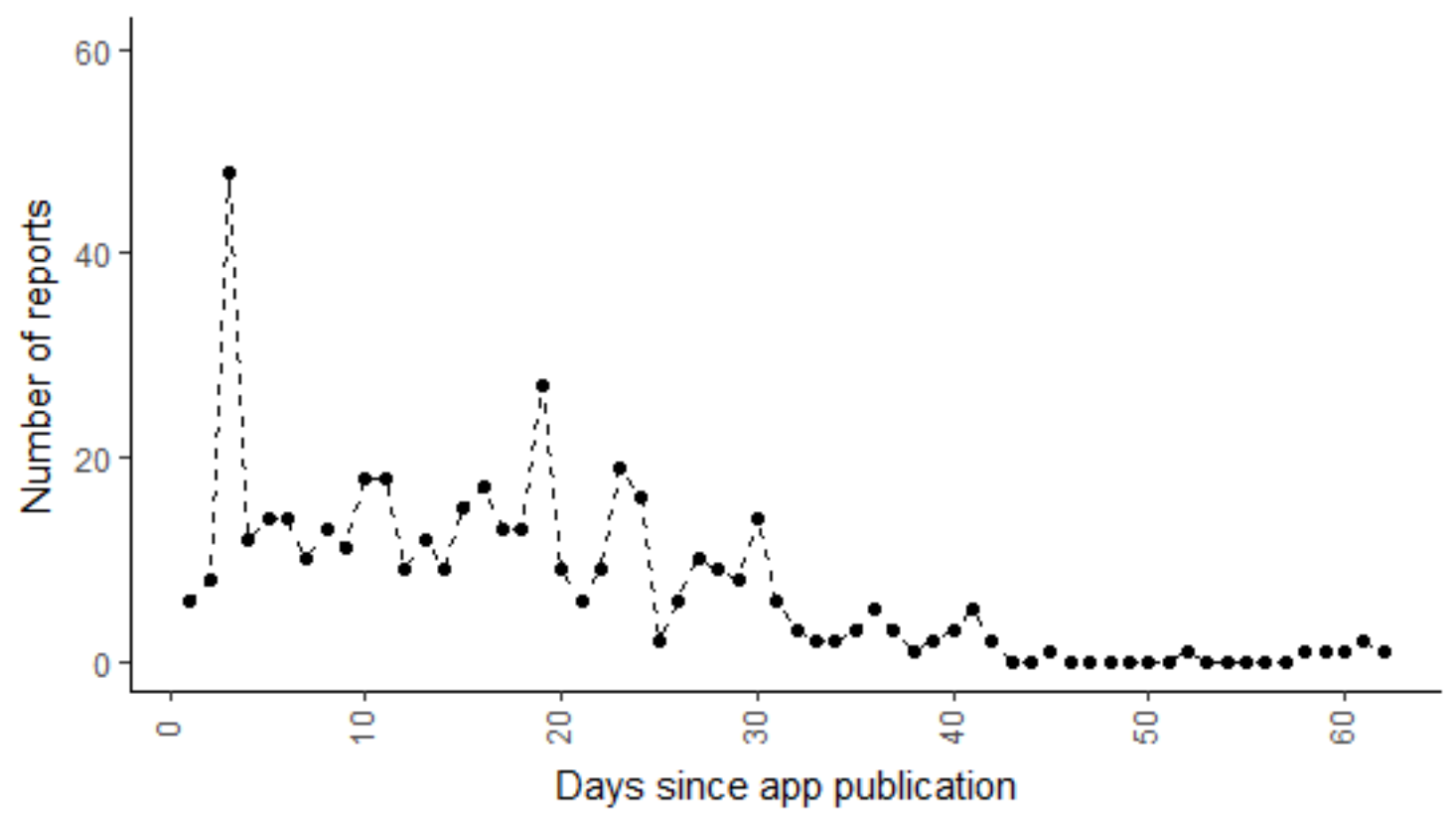

Figure VIII. Participation decrease over time observed at InseguridApp.

Three papers $(3,4,8)$ identified the issue that some crowdsourcing platforms do not include screening questions about variables that might bias the final results such as the users' previous experiences with crime. It can follow to recommend self-built applications to consider implementing pre-participation questionnaires to control for important variables.

Finally, while one of the key strengths identified by many papers was the ease with which large sample sizes can be acquired, some self-built mobile phone and website apps experienced small sample sizes and low response rates $(2,4,11,12,13,20,23,25)$. Many of these studies experienced issues in recruiting large samples, possibly due to a lack of incentives offered to participants, something which platforms such as FixMyStreet clearly offer (Solymosi et al. 2017). Pletikosa Cvijijk et al. (2015) found that people's main motivations to contribute 
to platforms by sharing information were that the application had helped them in the past by providing crime prevention tools, and being concerned about neighborhood safety. These findings could be utilized to incentivize participation in other app-based research. Similarly, in light of the large sample sizes of anonymous websites, Pánek et al. (2017b) suggest that building platforms which do not require registration may help to engage more groups.

Loosely related to sampling, the under-representation of certain areas and times relates to bias arising from unplanned sampling designs in which users decide when and where to report, a limitation cited by ten publications $(2,5,8,9,13,14,17,23,24,25)$. Innes (2015:217) argues that citizens "avoid those locations that they think might expose them to a source" of fear, which might result in the under-representations of those areas perceived as more dangerous. With respect to the under-representation of certain times, Blom et al. (2010) note that reports are five times higher at noon, while reports during the night are almost nonexistent. While this can be argued to a certain extent to reflect people's routine activity patterns (people report where they go, and when they are there), it does result in a systematically biased selection of routes. One approach to address this limitation is to record multiple journeys by participants, and randomly select from these certain journeys to ask about. This solution is implemented by the methodology of Walkcap, which allows for stratified random sampling of all routes walked by the participant in one day, through setting criteria for route selection, such as asking people first about night-time routes or routes crossing specific areas of interest (Figure IX). 


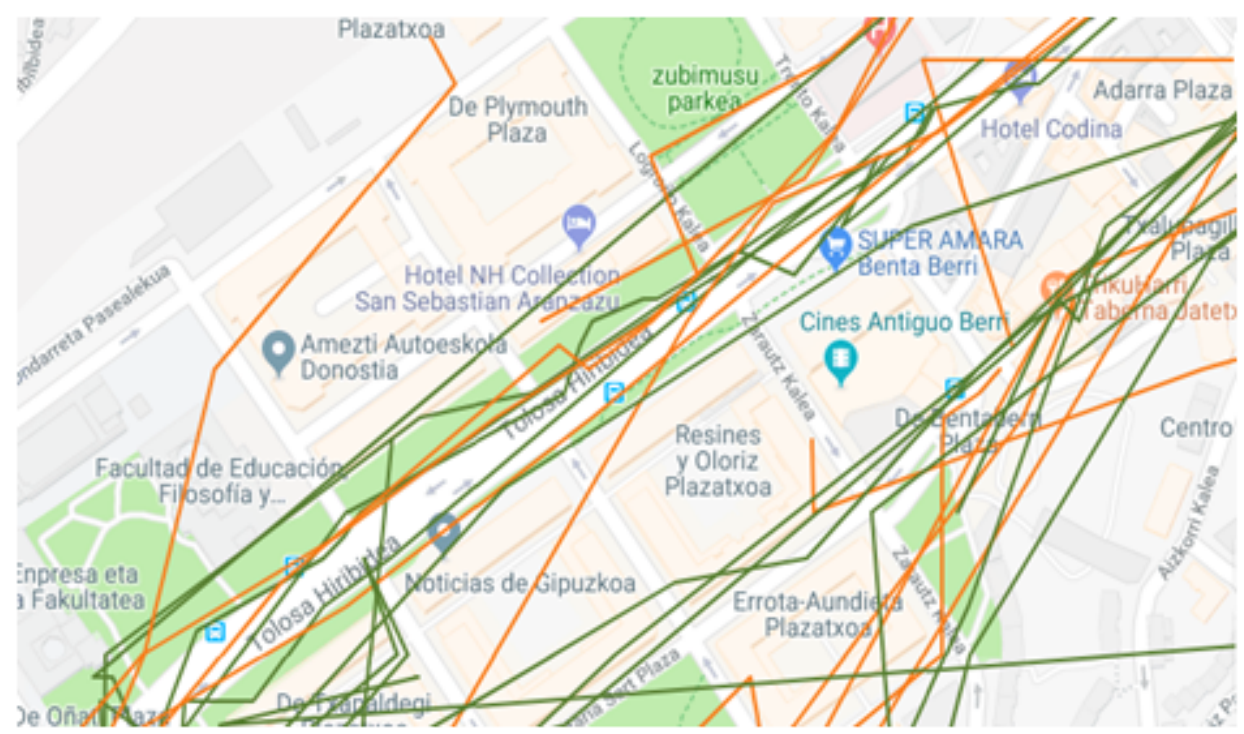

Figure IX. Routes captured by Walkcap are showed above Google Maps by connecting the registered GPS points. Orange routes belong to females and green ones to males.

Of the 34 evaluated routes, 4 were rated as "not safe" and 3 as "partially safe", therefore $20.6 \%$ of evaluations implied some degree of worry about safety. 15 routes were rated as "very safe" and 13 as "totally safe". A logistic regression between app used (FOCA + Inseguridad vs. Walkapp) and level of fear reported, to test the effect of using Walkapp compared to FOCA or InseguridApp shows that people are more likely to report fearful experiences with the Walkcap methodology; FOCA reports are 0.08 times as likely to report worry than Walkcap, while InseguridApp users 0.23 times as likely to report worry than Walkcap. While the participant groups are not matched, this does give some support to the hypothesis that the random route selection methodology of Walkcap results in capturing more fear experiences than the selfselection approach implemented in apps like FOCA and InseguridApp.

While contextual data collected allows some association of people's experience of fear with environmental or other factors, twelve papers highlight the difficulty to interpret results 
arising from the lack of ability to hold variables constant in real-world environments, leading to difficulty in interpreting the concrete reasons why fear increases in specific areas $(1,5,7,8$, $12,13,15,16,18,20,22,27)$. Limitations for interpreting results are also found by research making use of crowdsourced data from websites where images are assessed by users. For example, by asking users to report which place looks safer from two images, researchers can extract visual patterns from images, such as the presence of trees or gardens, the prevalence of residential houses, the number of people on street or the street width (e.g. $3,8,14,21$ ), and even the images' brightness and contrast (14), but not other sensory elements that might affect safety perceptions, such as noise, smell, temperature and weather conditions $(8,27)$. As stated by Traunmueller et al. (2016:76), "we experience a city not just through single images one by one, but though movement, developing a sense of place over time", and they discuss whether two dimensional images on a PC screen can be regarded as representative of real three dimensional urban spaces.

This links in with the concerns identified by seven papers around limitations to generalize results. Publications 2, 3, 5, 14, 15, 21 and 27 suggest that it is unclear if results obtained from studies using crowdsourced data can be generalized to other local authorities and countries, which might be characterized by different architectural and urbanistic styles, land use types, crime levels, cultural values, or other differences. To address these two limitations, some papers suggest that follow-up interviews would be helpful to interpret results obtained from crowdsourced data $(2,11,20,23,26)$. Others $(11,24)$ suggest taking advantage of built-in cameras available in most smartphones to provide further visual information. Leitner and Kounadi (2015) suggest asking information about the number and type of people that are present when participants report their emotions using a mobile app, or asking participants to wear 
wristband sensors to measure fear at the same time that data is recorded from direct participation.

The limitation whereby repeatedly asking about fear might increase/cause fear has implications not only in terms of the mere measurement effect, where simply by asking about a concept we affect it (Morwitz and Fitzsimons 2004), but also ethical concerns around possibly increasing fear and causing distress in study participants. Five publications argue that mobile phone applications that seek to capture the fear of crime might affect the emotions themselves $(7,10,13,23,25)$, as these "invite individuals to think about the personal relevance of crime, but importantly this is framed in terms of personal risk and threat" (Jackson and Gouseti 2015:212). Then, if the application sensitizes users to think about crime by increasing psychological proximity, the method itself might be artificially increasing fear emotions. Hamilton et al. (2011) also recognize that ethnographic research and surveys are needed to analyze the effect of mobile applications in changing human perceptions. Conversely, Blom et al. (2010:1850) argue that mobile apps might work as safety inducing services "that highlight the positive aspects of the urban spaces while ignoring the dark side". This is an issue that should be explored further in order to create discussion around the possible ethical issues around participation in such studies, as well as to establish the mechanisms through which the meremeasurement effect may influence data gathered in this way.

Finally, it was noted earlier that only seven studies collected temporally explicit data about people's experiences. Considering the innovation of situating fear of crime experiences in the context in which they occur, some of the studies which did not collect such data mentioned this in their limitations, recognizing a lack of temporal variability in some web-based measures. Five publications state that certain website platforms in which users note their perceived 
security by looking at pictures of different places struggle to capture the temporal variability of fear of crime $(3,4,8,16,25)$. Harvey et al. (2015) argue that crowdsourcing websites, such as Place Pulse, ask respondents to assess their perceived security at a snapshot in time without chronological and contextual knowledge, and do not analyze the temporal dimension of perceptions; and Solymosi and Bowers (2018) point out that such methods are difficult to sustain over long periods of time. The temporal element is well recorded by most mobile phone applications $(1,2,4,7,11,23,25)$ and some websites that distinguish between perceived safety "when it is dark" and "when there is a light" $(17,18,19)$ or record the exact day and time $(24)$. The recommendation is that if possible, all applications of such method consider not only location in place, but also point in time of the experience in order to build a complete picture of people's experiences in context.

Table 3. Summary table of limitations.

\begin{tabular}{|c|c|c|c|}
\hline \multicolumn{2}{|l|}{ Limitation } & $\mathbf{N}$ & Papers \\
\hline \multirow{4}{*}{ Sample issues } & $\begin{array}{l}\text { Participation } \\
\text { inequality. }\end{array}$ & $13(48.1 \%)$ & $\begin{array}{l}2,4,8,13,17,18,19,20,23,24 \text {, } \\
25,26,27 .\end{array}$ \\
\hline & $\begin{array}{l}\text { No screening } \\
\text { questions. }\end{array}$ & $3(11.1 \%)$ & $3,4,8$. \\
\hline & Sample attrition & $1(3.7 \%)$ & 2. \\
\hline & $\begin{array}{l}\text { Small sample sizes } \\
\text { and low response } \\
\text { rates. }\end{array}$ & $8(29.6 \%)$ & $2,4,11,12,13,20,23,25$ \\
\hline \multicolumn{2}{|c|}{$\begin{array}{l}\text { Under-representation of certain areas and } \\
\text { times. }\end{array}$} & $10(37.0 \%)$ & $2,5,8,9,13,14,17,23,24,25$ \\
\hline \multicolumn{2}{|c|}{ Difficult to interpret results. } & $12(44.4 \%)$ & $\begin{array}{l}1,5,7,8,12,13,15,16,18,20, \\
22,27 .\end{array}$ \\
\hline \multicolumn{2}{|c|}{ Limitations to generalise results. } & $7(25.9 \%)$ & $2,3,5,14,15,21,27$ \\
\hline \multicolumn{2}{|c|}{$\begin{array}{l}\text { Repeatedly asking about fear might } \\
\text { increase/cause fear. }\end{array}$} & $5(18.5 \%)$ & $7,10,13,23,25$ \\
\hline \multicolumn{2}{|c|}{$\begin{array}{l}\text { Lack of temporal variability in some web- } \\
\text { based measures. }\end{array}$} & $5(18.5 \%)$ & $3,4,8,16,25$ \\
\hline
\end{tabular}




\section{Discussion}

Our systematic review identified 576 papers that mention the use of app-based or crowdsourced data collection, and focus on the fear of crime or associated constructs, of which 27 met our inclusion criteria. These papers were synthesized to consolidate the strengths and limitations they identified, to establish good practice, and map the route for future work in developing app-based and crowdsourcing data collection as a robust methodological approach to study fear of crime as a place-based, context-specific experience.

The main strength identified by our systematic review is the ability to collect precise spatial and temporal data to situate fear of crime events, which can be linked to valuable auxiliary information about individual and environmental characteristics. This strength was illustrated with analysis from FOCA and InseguridApp, showing the ability to append visual audit of the high fear places, and the ability to approximate dynamic variables such as familiarity with an area. Other strengths include technical advantages over traditional survey methodologies, such as reduced costs, and the ease to apply results to policy and practice, lending empirical support to a place-based approach to fear of crime.

A key theme to emerge from the limitations of using app-based and crowdsourcing methods to study fear of crime was around issues with sampling bias and generalizability. We propose that future research in this field address the issues raised here. Suggestions identified in this review were to explore participation motivation, the use of sensors, or interviews or follow-up questionnaires. Similarly, some studies suggested the use of statistical or computational modeling approaches. Regarding under-representation of areas due to avoidance, one possible approach to address this was proposed through asking users to report retrospectively about a randomly selected route from a sample collected from them that day. 
Exploratory analysis of Walkcap data showed that participants using this app were more likely to report worry situations than with apps using the self-report methodology. The issues introduced by sampling are multifaceted, and a variety of approaches to fully explore and to eventually account for them should be the focus of research in this area in the near future.

The suggestions around using sensors and video-capture tap into one issue not addressed by the papers in this review: the extent to which people disclose their true feelings of worry. While we begin to tap into the situation-specific experience with worry that people experience as they go about their routine activities, we still rely on people recognizing an incident of worry, and then reporting for the study. One approach is to apply sensing methodologies to explore fear of crime and perceived insecurity (e.g. Castro-Toledo et al. 2017; De Silva, Warusavitharana and Rathayake 2016). The use of heart rate and skin conductance measures to explore emotional reactions offers an increase in validity and may contribute to overcome issues and limitations of self-report instruments such as social desirability and lack of spontaneity. In spite of the potential of physiological measures (Warr 2000), this approach has not been widely adopted to study fear of crime. Furthermore, research on the contextual elements that trigger fear of crime would benefit with the increase use of eye tracking techniques (Crosby and Hermens 2018; Davoudian and Raynham 2012; Guedes et al. 2013; Kim et al. 2014). Eye tracking (recording where people focus) allows insights to the understanding specifically what features of (un)safe scenarios most capture the attention of individuals. For instance, Guedes et al. (2013) found that when presented with images of areas rated unsafe, individuals tend to focus more frequently on contextual cues such as graffiti, windows bars, tunnels and non-cared-for vegetation. This could help address the 'difficult to interpret' limitation identified in the systematic review. Future research could do well by combining app-based measures with such 
sensing methodologies to further uncover the context-specific experiences people have with fear of crime.

Finally, as the limitation 'repeatedly asking about fear might increase/cause fear' suggests, it is important to maintain discussions around the ethical implications of such methodologies, as raised by the limitation that identified the possibility of generating fear in participants of such studies. It is possible that there are other risks associated with this emerging method, and researchers have a duty to consider these as they develop.

Overall, the papers in this review all share an approach that allows the re-framing of fear of crime as a place-based, contextually specific event that may lend itself to problem-solving approaches. Much like a place-based approach for crime, applying these methodologies to fear of crime make possible the measurement of the fear of crime construct in a way that allows such exploration. By building on the strength and working to address the limitations discussed in this review, we can explore fear of crime as a function of people's experiences in their immediate environments, and inform evidence-based policy making and urban planning for safer places.

\section{Conclusion}

This paper has synthesized the findings from the various pilot projects exploring the feasibility of a new methodological approach to the study of perception of crime and place. By doing so, we put forward app-based and crowdsourcing methodologies as a way to collect empirical data to support a place-based and context-specific conceptualization of fear of crime and perception of place. 
The systematic review identified many strengths that drive the adoption of these approaches, most prominently the fine-grained spatial (and in some cases temporal) data which can be collected about people's subjective experiences. This lends itself to mapping and the exploration of contextual factors associated with the phenomena alongside the person-specific factors at unprecedented scale and ease of collection. However, for such information to support research as well as to inform policy, it must become generalizable, and build strong reliability and validity measures. Through synthesizing the identified limitations, we make suggestions for future work to address these, in particular those around sampling, to move this area forward.

Through presenting the strengths and limitations identified, illustrated with empirical examples, we provide a comprehensive reference for the potential of such methods to reconceptualize fear of crime as an experience in time and place that is a function of personspecific, as well as environmental factors. Once established, this new approach makes possible to consider place-based factors in fear of crime research with empirical evidence, as was demonstrated here with the importance of familiarity with an area, identifying context-specific environmental features that influence people's experiences of fear of crime. 


\section{References}

Armitage, R. (2017). Crime prevention through environmental design. In R. Wortley, \& M. Townsley (Eds.), Environmental Criminology and Crime Analysis. 2nd Edition (pp. 259-285). London: Routledge.

Bethlehem, J., \& Biffignandi, S. (2012). Handbook of web surveys. Hoboken: Wiley.

Birenboim, A. (2015). New approaches to the study of tourist experiences in time and space. Tourism Geographies, 18(1), 9-17.

Bivand, R. S. (2010). Exploratory spatial data analysis. In M. M. Fischer, \& A. Getis (Eds.) Handbook of applied spatial analysis (pp. 219-254). Berlin, Heidelberg: Springer.

Blom, J., Viswanathan, D., Go, J., Spasojevic, M., Acharya, K., \& Ahonius, R. (2010). Fear and the city - Role of mobile services in harnessing safety and security in urban contexts. In CHI'10 Proceedings of the SIGCHI Conference on Human Factors in Computing Systems. (pp. 1841-1850).

Braga, A. A., Papachristos, A. V., \& Hureau, D. M. (2014). The effects of hot spots policing on crime: An updated systematic review and meta-analysis. Justice Quarterly, 31(4), 633663.

Buil-Gil, D. (2016). InseguridApp: Estudio piloto de los patrones de distribución espaciotemporal de los enclaves del miedo (al crimen) en Elche a partir de una nueva aplicación móvil. Master thesis, Miguel Hernandez University.

Buil-Gil, D., Moretti, A., Shlomo, N., \& Medina, J. (2019). Worry about crime in Europe: A model-based small area estimation from the European Social Survey. European Journal of Criminology. https://doi.org/10.1177/1477370819845752

Burnap, P., Rana, O. F., Avis, N., Williams, M., Housley, W., Edwards, A., Morgan, J., and Sloan, L. (2015). Detecting tension in online communities with computational Twitter analysis. Technological Forecasting \& Social Change, 95, 96-108.

Candeia, D., Figueiredo, F., Andrade, N., \& Quercia, D. (2017). Multiple images of the city: Unveiling group-specific urban perceptions through a crowdsourcing game. In $H T^{\prime} 17$ Proceedings of the $28^{\text {th }}$ ACM Conference on Hypertext and Social Media Pages (pp. 135144).

Castro-Toledo, F. J., Perea-García, J. O., Bautista-Ortuño, R., \& Mitkidis, P. (2017). Influence of environmental variables on fear of crime: Comparing self-report data with physiological measures in an experimental design. Journal of Experimental Criminology, 13(4), 537-545.

Ceccato, V., Uittenbogaard, A., \& Bamzar, R. (2013). Security in Stockholm's underground stations: The importance of environmental attributes and context. Security Journal, 26(1), 33-59.

Chappell, A. T., Monk-Turner, E., \& Payne, B. K. (2011). Broken windows or window breakers: The influence of physical and social disorder on quality of life. Justice Quarterly, 28(3), 522-540. 
Chataway, M, L., Hart, T. C., Coomber, R., \& Bond, C. (2017). The geography of crime fear: A pilot study exploring event-based perceptions of risk using mobile technology. Applied Geography, 86, 300-307.

Clarke, R. V. (1983). Situational crime prevention: Its theoretical basis and practical scope. Crime and Justice, 225-256.

Clarke, R. V., \& Bowers, K. (2017). Seven misconceptions of situational crime prevention. In N. Tilley, \& A. Sidebottom (Eds.), Handbook of Crime Prevention and Community Safety. 2nd Edition (pp. 109-142). London: Routledge.

Collins, R. E. (2016). Addressing the inconsistencies in fear of crime research: A metaanalytic review. Journal of criminal justice, 47, 21-31.

Csikszentmihalyi, M. (2014). Flow and the foundations of positive psychology. The collected works of Mihaly Csikszentmihalyi. Dordrecht: Springer.

De Silva, C. S., Warusavitharana, E. J., \& Ratnayake, R. (2016). Application of open source hardware and software in assessing the varying levels of perceived safety in cities. In Proceedings of the 9th International Conference of Faculty of Architecture Research Unit (FARU) (pp. 236-249), University of Moratuwa, Sri Lanka.

Doran, B. J., \& Burgess, M. B. 2012. Putting fear of crime on the map. London: Springer

Dubey, A., Naik, N., Parikh, D., Raskar, R., \& Hidalgo, C. A. (2016). Deep learning the city: Quantifying urban perception at a global scale. Pp. 196-212, In Computer Vision European Conference on Computer Vision 2016 (pp. 169-212).

Elliott, M. R., \& Valliant, R. (2017). Inference for nonprobability samples. Statistical Science, 32(2), 249-264.

Erete, S., Nicole, L., Mumm, J., Boussayoud, A., \& Ogbonnaya-Obguru, I. F. (2016). "That Neighborhood is Sketchy!": Examining Online Conversations about Social Disorder in Transitioning Neighborhoods. In CHI EA '16 Proceedings of the 2016 CHI Conference Extended Abstracts on Human Factors in Computing Systems (pp. 1180-1186).

Fattah, E. A., \& Sacco, V. F. (1989). Crime and victimisation of the elderly. New York: Springer-Verlag.

Fisher, B., \& Nasar, J. J. (1995). Fear spots in relation to microlevel physical cues: Exploring the overlooked. Journal of Research in Crime and Delinquency, 32(2), 214-239.

Foster, S., Giles-Corti, B, \& Knuiman, M. (2010). Neighbourhood design and fear of crime: A social-ecological examination of the correlates of residents' fear in new suburban housing developments. Health and Place, 16(6), 1156-1165.

Gómez, F., Torres, A., Galvis, J., Camargo, J., \& Martínez, O. (2016). Hotspot mapping for perception of security. In 2016 IEEE International Smart Cities Conference (ISC2).

Gravel, J., Bouchard, M., Descormiers, K., Wong, J. S., \& Morselli, C. (2013). Keeping promises: A systematic review and a new classification of gang control strategies. Journal of Criminal Justice, 41(4), 228-242.

Gray, E., Jackson, J., \& Farrall, S. (2012). In search of the fear of crime: Using interdisciplinary insights to improve the conceptualisation and measurement of everyday 
insecurities. In D. Gadd, S. Karstedt, \& S. F. Messner (Eds.), The SAGE handbook of criminological research methods (pp. 268-281). London: SAGE.

Guedes, I., Fernandes, P., da Agra, C., \& Cardoso, C. (2014). Studying the contextual cues associated with fear of crime through eye tracking techniques. In C. da Agra, C. Cardoso, J. de Maillard, C. O'Reily, P. Ponsaers, \& J. Shapland (Eds.) Criminology, security and justice. Methodological and epistemological issues (pp. 57-82). Apeldoorn: Maklu.

Hale, C. (1996). Fear of crime: A review of the literature. International Review of Victimology, 4(2), 79-150.

Hamilton, M., Salim, F., Cheng, E., \& Choy, S. (2011). Transafe: A crowdsourced mobile platform for crime and safety perception management. SIGCAS Computers and Society, 41(2), 32-37.

Harvey, C., Aultman-Hall, L., Hurley, S. E., \& Troy, A. (2015). Effects of skeletal streetscape design on perceived safety. Landscape and Urban Planning, 142, 18-28.

Hedayati Marzbali, M., Aldrin, A., \& Mohammad Javad, M. T. (2016). The effectiveness of interventions in the built environment for improving health by addressing fear of crime. International Journal of Law, Crime and Justice, 45, 120-140.

Hinkle, J. C., \& Weisburd, D. (2008). The irony of broken windows policing: A micro-place study of the relationship between disorder, focused police crackdowns and fear of crime. Journal of Criminal justice, 36(6), 503-512.

Innes, M.. (2004). Signal crimes and signal disorders: notes on deviance as communicative action. The British Journal of Sociology, 55(3), 335-355.

Innes, M. (2015). 'Place-ing' fear of crime. Legal and Criminological Psychology, 20, 215217.

Jackson, J., \& Gouseti, I. (2015). Psychological proximity and the construal of crime: A commentary on 'Mapping fear of crime as a context-dependent everyday experience that varies in space and time'. Legal and Criminological Psychology, 20, 212-214.

Jones, P, Drury, R., \& McBeath, J. (2011). Using GPS-enabled mobile computing to augment qualitative interviewing: Two case studies. Field Methods, 23(2), 173-187.

Kim, J., Cha, M., \& Sandholm, T. (2014). SocRoutes: Safe routes based on tweet sentiments. In $W W W$ ' 14 Companion. Proceedings of the 23rd International Conference on World Wide Web (pp. 178-182).

Kyttä, M., Kuoppa, J., Hirvonen, J., Ahmadi, E., \& Tzoulas, T. (2014). Perceived safety of the retrofit neighborhood: A location-based approach. Urban Design International, 19(4), 311-328.

LaGrange, R. L., Ferraro, K. F., \& Supancic, M. (1992). Perceived risk and fear of crime: Role of social and physical incivilities. Journal of Research in Crime and Delinquency, 29(3), 311-334.

Leitner, M., \& Kounadi, O. (2015). Mapping fear of crime as a context-dependent everyday experience that varies in space and time. Legal and Criminological Psychology, 20, 218221. 
Li, X., Zhang, C., \& Li, W. (2015). Does the visibility of greenery increase perceived safety in urban areas? Evidence from the Place Pulse 1.0 dataset. ISPRS International Journal of Geo-Information, 4, 1166-1183.

Lim, H., \& Wilcox, P. (2017). Crime-reduction effects of open-street CCTV: Conditionality considerations. Justice Quarterly, 34(4), 597-626.

Lorenc, T., Petticrew, M., Whitehead, M., Neary, D., Clayton, S., Wright, K., Thomson, H., Cummins, S., Sowden, A., \& Renton, A. (2013). Fear of crime and the environment: systematic review of UK qualitative evidence. BMC Public Health, 14(496), 1-8.

Loukaitou-Sideris, A. (2006). Is it Safe to Walk?1 Neighborhood Safety and Security Considerations and Their Effects on Walking. Journal of Planning Literature, 20(3), 219232.

MacKerron, G. (2011). Happiness and environment quality. $\mathrm{PhD}$ thesis, London School of Economics and Political Science.

Morwitz, V. G., \& Fitzsimons, G. J. (2004). The mere-measurement effect: Why does measuring intentions change actual behavior?. Journal of Consumer Psychology, 14(1-2), 64-74.

Naik, N., Philipoom, J., Raskar, R., \& Hidalgo, C. (2014). Streetscore - Predicting the perceived safety of one million streetscapes. In Proceedings of the IEEE Conference on Computer Vision and Pattern Recognition Workshops (pp. 779-785).

Nasar, J. L., \& Jones, K. M. (1997). Landscapes of fear and stress. Environment and Behavior, 29(3), 291-323.

Newman, O. (1972). Defensible Space: Crime Prevention Through Urban Design. New York: Macmillan.

Ordonez, V., \& Berg, T. L. (2014). Learning high-level judgements of urban perception. In D. Flett, T. Pajdla, B. Schiele, \& T. Tuytelaars (Eds.), Computer vision - ECCV 2014. 13th European Conference Zurich, Switzerland, September 6-12, 2014 Proceedings, Part $V I$ (pp. 494-510). Chennai: Springer.

Pánek, J., Mařincová, L., Putalová, L., Hájek, J., \& Marek, L. (2017a). Crowdsourcing of environmental health quality perceptions: A pilot study of Kroměříž, Czech Republic. In M. Leitner, \& J. J. Arsanjani Citizen empowered mapping. Geotechnologies and the environment. Volume 18 (pp. 261-280). Cham: Springer.

Pánek, J., Pászto, V., \& Marek, L. (2017b). Mapping emotions: Spatial distribution of safety perception in the city of Olomouc. In I. Ivan, A. Singleton, J. Horák, \& T. Inspektor (Eds.), The rise of big spatial data. Lecture notes in geoinformation and cartography. Cham: Springer.

Pánek, J., Pászto, V., \& Šimáček, P. (2018). Spatial and temporal comparison of safety perception in urban spaces. Case study of Olomouc, Opava and Jihlava. In I. Ivan, J. Horák, \& T. Inspektor (Eds.), Dynamics in Glscience. Lecture notes in geoinformation and cartography (pp. 333-346). Cham: Springer. 
Pletikosa Cvijijk, I., Kadar, C., Ivan, B., \& Te, Y. F. (2015). Towards a crowdsourcing approach for crime prevention. In UbiComp/ISWC'15 Adjunct Adjunct Proceedings of the 2015 ACM International Joint Conference on Pervasive and Ubiquitous Computing and Proceedings of the 2015 ACM International Symposium on Wearable Computers (pp. 1367-1372).

Pődör, A., Révész, A., Rácskai, P., \& Sasvár, Z. (2016). Measuring citizens’ fear of crime using a web application: A case study. GI_Forum, 2, 123-133.

Politécnico di Milano DiAP, IAU île-de-France, \& Regione Emilia Romagna. (2007). Planning Urban Design and Management for Crime prevention, Handbook. Brussels: European Commission Directorate-General Justice, Freedom and Security.

Porzi, L., Rota Bulò, S., Lepri, B., \& Ricci, E. (2015). Predicting and understanding urban perception with Convolutional Neural Networks. In MM'15 Proceedings of the 23rd ACM international conference on Multimedia (pp. 139-148).

Quercia, D., Aiello, L. M., Schifanella, R., \& Davies, A. (2015). The digital life of walkable streets. In Proceedings of the 24th International Conference on World Wide Web (pp. 875884).

Salesses, P., Schechtner, K., \& Hidalgo, C. A. (2013). The collaborative image of the city: Mapping the inequality of urban perception. PLOS ONE, 8(7), e68400.

San Juan, C., Vozmediano, L., \& Vergara, A. I. (2010). Self-protective behaviour against crime in urban settings: Diagnosis through surveys and Geographic Information Systems. Psyecology, 1(2), 253-262.

Scarborough, B. K., Like-Haislip, T. Z., Novak, K. J., Lucas, W. L., \& Alarid, L. F. (2010). Assessing the relationship between individual characteristics, neighborhood context, and fear of crime. Journal of Criminal Justice, 38(4), 819-826.

Shah, S., Bao, F., Lu, C. T., \& Chen, I. R. (2011). CROWDSAFE: Crowd sourcing of crime incidents and safe routing on mobile devices. In GIS ' 11 Proceedings of the $19^{\text {th }} A C M$ SIGSPATIAL International Conference on Advances in Geographic Information Systems (pp. 521-524).

Solymosi, R., \& Bowers, K. (2018). The role of innovative data collection methods in advancing criminological understanding. In G. J. N. Bruinsma, \& S. D. Johnson (Eds.), The Oxford Handbook of Environmental Criminology (pp. 210-237). New York: Oxford University Press.

Solymosi, R., Bowers, K., \& Fujiyama, T. (2015). Mapping fear of crime as a contextdependent everyday experience that varies in space and time. Legal and Criminological Psychology, 20, 193-211.

Solymosi, R., Bowers, K. J., \& Fujiyama, T. (2017). Crowdsourcing subjective perceptions of neighbourhood disorder: Interpreting bias in open data. The British Journal of Criminology, 58(4), 944-967. 
Swatt, M. L., Varano, S. P., Uchida, C. D., \& Solomon, S. E. (2013). Fear of crime, incivilities, and collective efficacy in four Miami neighborhoods. Journal of Criminal Justice, 41(1), 1-11.

Traunmueller, M., Marshall, P., \& Capra, L. (2015). Crowdsourcing safety perceptions of people: Opportunities and limitations. In T. Y. Liu, C. N. Scollon, \& W. Zhu (Eds.), Social informatics. $7^{\text {th }}$ International Conference, SocInfo 2015 (pp. 120-135). Switzerland: Springer.

Traunmueller, M., Marshall, P. \& Capra, L. (2016). “... when you're a stranger”: Evaluating safety perceptions of (un)familiar urban places. In Proceedings of the Second International Conference on IoT in Urban Space (pp. 71-77).

Vozmediano, L., Azanza, M., \& Villamane, M. (2017). Desarrollando y probando una app para analizar la influencia de la seguridad percibida en la movilidad a pie: un trabajo multidisciplinar con profesorado y alumnado de Psicología e Ingeniería. La educación, base para los Objetivos de Desarrollo Sostenible, Bilbao.

Warr, M. \& Stafford, M. (1983). Fear of victimization: A look at the proximate causes. Social Forces, 61(4), 1033-1043.

Wickramasekera, N., Wright, J., Elsey, H., Murray, J., \& Tubeuf, S. (2015). Cost of crime: A systematic review. Journal of Criminal Justice, 43(3), 218-228.

Williams, M. L., Burnap, P., \& Sloan, L. (2017). Crime sensing with big data: The affordances and limitations of using open-source communications to estimate crime patterns. British Journal of Criminology, 57, 320-340.

Wortley, R., \& Mazerolle, L. (2008). Environmental criminology and crime analysis: situating the theory, analytic approach and application. In R. Wortley, \& L. Mazerolle (Eds.) Environmental criminology and crime analysis (pp. 1-18). New York: Willan.

[1] We did not include use of boolean logic to pick up variations on wording.

[2] odds ratio $=0.08,95 \%$ confidence intervals: $0.03-0.23, p<0.001, \mathrm{AIC}=393.21$, model chi square $=0.000005$, likelihood ratio $r$ square $=0.059$.

[3] odds ratio $=0.23,95 \%$ confidence intervals: $0.09-0.62, p=0.002, A I C=393.21$, model chi square $=0.000005$, likelihood ratio $r$ square $=0.059$. 
Appendix A. Translation of InseguridApp menus 1 and 2

\section{Personal information}

Before you report your perceptions of security, we ask you to fill out the form below with your personal information:

Date of birth
Sex Male Female
Country of
birth
Province of
residence
Municipality of
residence
Employment
status
Marital
status
Level of
education

\section{(6) Your fear of crime}

The aim of this question is to know your perception of security in open environments. Please, answer this question only if you are in an open public space.

In this moment and place, how fearful are you of becoming a victim of a crime (burglary, robbery, assault...)?

Not at all fearful

Not very fearful

Fairly fearful

- Very fearful

\section{Save}




\section{Appendix B. Translation of Walkcap menus 1 and 2}
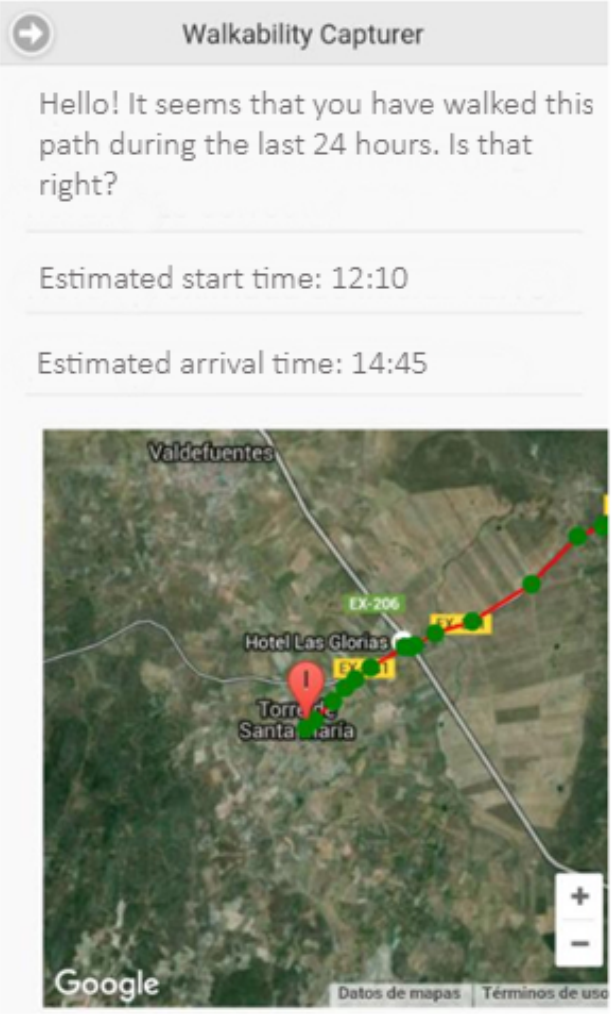

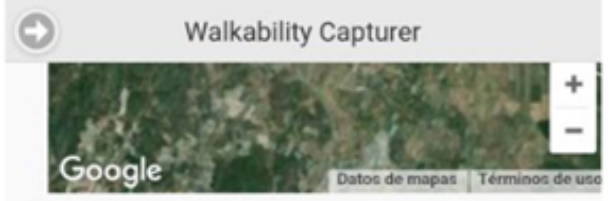

Why did you walk this path? If more than one reason applies, choose the most important one:

- Commuting to and from work or school/college/university

Travelling during one's working time, as part of job

Family duties (for example, walk children to school, to hospital...)

Leisure and free time

Shopping 